
Science

\title{
Groundnut (Arachis hypogaea L.) improvement in sub-Saharan Africa: a review
}

Seltene Abady, Hussein Shimelis, Pasupuleti Janila \& Jacob Mashilo

To cite this article: Seltene Abady, Hussein Shimelis, Pasupuleti Janila \& Jacob Mashilo (2019): Groundnut (Arachis hypogaea L.) improvement in sub-Saharan Africa: a review, Acta Agriculturae Scandinavica, Section B — Soil \& Plant Science, DOI: 10.1080/09064710.2019.1601252

To link to this article: https://doi.org/10.1080/09064710.2019.1601252

曲 Published online: 07 Apr 2019.

Submit your article to this journal

View Crossmark data $₫$ 


\title{
Groundnut (Arachis hypogaea L.) improvement in sub-Saharan Africa: a review
}

\author{
Seltene Abady ${ }^{a, b, c, d}$, Hussein Shimelis ${ }^{c}$, Pasupuleti Janila ${ }^{d}$ and Jacob Mashiloc

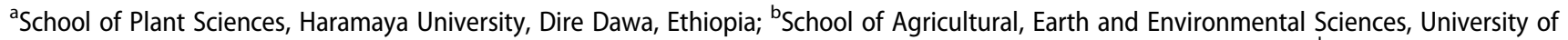 \\ KwaZulu-Natal, Scottsville, South Africa; ' $A$ African Centre for Crop Improvement (ACCI), Pietermaritzburg, South Africa; ${ }^{d}$ International Crops \\ Research Institute for Semi-Arid Tropics (ICRISAT), Telangana, India
}

\section{ABSTRACT}

Groundnut (Arachis hypogaea L.) is a multi-purpose legume crop widely cultivated in sub-Saharan Africa (SSA). However, yield levels of the crop has remained relatively low in SSA owing to a range of biotic, abiotic and socio-economic constraints. A dedicated groundnut improvement programme integrating new tools and methodologies to breed varieties suitable for current and emerging agro-ecologies and market needs is essential for enhanced and sustainable groundnut production in SSA. The objective of this review is to highlight breeding progress, opportunities and challenges on groundnut improvement with regard to cultivar development and deployment in SSA in order to guide future improvement of the crop. The review analysed the role of new tools in breeding such as, high-throughput and automated phenotyping techniques, rapid generation advancement, single seed descent approach, marker-assisted selection, genomic selection, next-generation sequencing, genetic engineering and genome editing for accelerated breeding and cultivar development of groundnut.

\section{ARTICLE HISTORY}

Received 18 January 2019

Accepted 25 March 2019

\section{KEYWORDS}

Abiotic production constraints; aflatoxin content; groundnut breeding; genotyping; phenotyping

\section{Introduction}

Groundnut (Arachis hypogaea L., $2 n=4 x=40$, AABB) is self-pollinating allotetraploid legume crop belonging to the Fabaceae family (Janila et al. 2013). Groundnut seeds are a rich source of oil (35-56\%), protein (25$30 \%)$, carbohydrates (9.5-19.0\%), minerals $(\mathrm{P}, \mathrm{Ca}, \mathrm{Mg}$ and $K$ ) and vitamins ( $E, K$ and $B$ ) (Gulluoglu et al. 2016). The crop has various industrial uses including products such as food, feed, paints, lubricants and insecticides (Variath and Janila 2017). Further, groundnut is an ideal crop in rotational systems to improve soil fertility due to its natural ability to fix atmospheric nitrogen (Jaiswal et al. 2017).

Groundnut yields in sub-Saharan Africa (SSA) are generally low $(964 \mathrm{~kg} / \mathrm{ha}$ ) which is far less than potential yields of up to $3500 \mathrm{~kg} / \mathrm{ha}$ reported elsewhere (African Institute of Corporate Citizenship 2016). The low yield levels of groundnut in SSA is attributed to various stresses such as abiotic (drought and low soil fertility) and biotic [pests such as aphids (Aphis craccivora Koch), leafminer (Aproarema modicella Deventer), thrips (Thrips palmi Karny, Frankiniella schultzie Trybom, Scirtothrips dorsalis Hood and Caliothrips indicus) and termites (Isoptera)], and diseases (i.e. groundnut rosette disease, leaf spot, rust). Further, farmers in the region are cultivating unimproved varieties using poor agronomic practices and with limited access to extension and advisory services (Alemayehu et al. 2014; Debele and Amare 2015; Coulibaly et al. 2017; Desmae and Sones 2017; Mastewal et al. 2017). For example, in Senegal, water stress occurring during flowering and seed filling period reduced groundnut shelled yield by 33 and $50 \%$, respectively (Faye et al. 2016). Groundnut rosette disease causes more severe yield losses than any of the groundnut viral diseases in the region (Okello et al. 2010). Early and late leaf spots caused $100 \%$ yield loss in Ghana (Gaikpa et al. 2015).

In SSA, efforts are being made to improve groundnut yield levels which aided in the release of few genetically superior and improved groundnut varieties (Desmae et al. 2017). Reports showed that introduced groundnut varieties had considerable resistance to both biotic and abiotic stresses (Monyo and Varshney 2016; Coulibaly et al. 2017). In addition, groundnut varieties with some desirable quality attributes such as high oil content and larger seed size for confectionery purposes have also been recently popularised (Okello et al. 2016, 2018; Amare et al. 2017). Despite past successful efforts, there has been limited breeding progress in developing groundnut varieties combining desirable agronomic and quality attributes such as high fatty acid content in combination with high yield, short maturity, drought

CONTACT Jacob Mashilo @ jacobmashilo@yahoo.com E African Centre for Crop Improvement (ACCI), Private Bag X01, Scottsville 3209, Pietermaritzburg, South Africa

2019 Informa UK Limited, trading as Taylor \& Francis Group 
tolerance or resistance to foliar diseases which are the needs and preferences of farmers and groundnut value chains (Okello et al. 2010, 2018; Desmae et al. 2017). Therefore, it is an overriding consideration to develop varieties with various quality attributes to boost productivity and quality of the crop in order to satisfy farmer's demands and value chains for food security and regional and local markets. An integrated groundnut improvement incorporating conventional and molecular breeding tools may aid in accelerated groundnut cultivars development and deployment in SSA. Therefore, the objective of this review is to highlight breeding progress, opportunities and challenges on groundnut improvement with regards to cultivar development and deployment in SSA in order to guide future improvement of the crop.

\section{Status of groundnut production}

Area under groundnut cultivation and total production have shown marked increases during the period 19972016 in SSA (FAOSTAT 2016). For instance, Angola and Cameroon recorded rapid increase in both cultivated area and production between 1997 and 2016. Conversely, in Botswana and South Africa both cultivated area and production level declined between 1997 and 2016. Variable yield levels have also been observed for most SSA countries during the period 1997-2016. Angola recorded groundnut yield levels varying from 500 (during 1997) to $712 \mathrm{~kg} / \mathrm{ha}$ (2016) which was a yield improvement of $30 \%$. Cameroon recorded the lowest groundnut yield of $281 \mathrm{~kg} / \mathrm{ha}$ in 1997 to the highest yield level of $1648 \mathrm{~kg} / \mathrm{ha}$ in 2016, which was an increase of $83 \%$. Contrastingly, South Africa and Mozambique showed a decline in groundnut yields between 1997 and 2016. Mozambique, Angola and Botswana recorded the lowest mean groundnut yields of 349,442 and $491 \mathrm{~kg} / \mathrm{ha}$ averaged across period 1997-2016, respectively. Ghana, Cameroon, Nigeria and South Africa have recorded the top yield levels $>1000 \mathrm{~kg} / \mathrm{ha}$ across the same years. In general, increased groundnut production in SSA emanated from the expansion of agricultural lands. Some reports (Monyo and Varshney 2016; Kebede et al. 2017) indicated that groundnut yields of 1,700-2,500 kg per/ha can be realised using elite/ improved varieties in SSA despite that farmers yet continue cultivating unimproved local varieties. Famer participatory variety selection is considered to be a useful tool to enhance access to improved seed and increased adoption rate of improved varieties in SSA (Ndjeunga 2010; Okello et al. 2010; Monyo and Varshney 2016; Motagi et al. 2016; Desmae et al. 2017).

\section{Progress on groundnut variety development in SSA}

In the last two decades, more than 100 improved and high yielding groundnut genotypes have been introduced, developed and released for cultivation in SSA (Desmae et al. 2017). Some of the released varieties are cultivated in several SSA countries (Table 1). For example, cultivar JL 24 is widely grown in Malawi, Mozambique and South Africa due to its considerable level of drought tolerance and early maturity (Desmae et al. 2017). The reported yield levels of this variety in Malawi, Mali and Niger is 1500, 2000 and $2000 \mathrm{~kg} / \mathrm{ha}$, in that order (Minde et al. 2008; Ndjeunga 2010). Variety ICIAR 19 BT is cultivated in Nigeria and Niger due to its early maturity, high yield levels, high oil content and resistance to groundnut rosette disease.

Table 1. Some of the major groundnut varieties cultivated in sub-Saharan Africa.

\begin{tabular}{|c|c|c|c|}
\hline Name or code & Local names in different countries & Attributes & References \\
\hline ICG 12991 & $\begin{array}{l}\text { Baka (Malawi) Serenut } 4 \text { T (Uganda), Nametil (Mozambique) and } \\
\text { Zambia }\end{array}$ & Early maturity, drought tolerance & $\begin{array}{l}\text { Deom et al. (2006), Muitia } \\
\text { (2011), Kanyika et al. (2015) }\end{array}$ \\
\hline JL 24 & $\begin{array}{l}\text { Sameké (Mali), Kakoma (Malawi), ICG } 7827 \text { (Mozambique), Luena } \\
\text { (Zambia), JL24 (Congo), JL } 24 \text { (Sierra Leone), JL24 (South Africa) }\end{array}$ & $\begin{array}{l}\text { Early maturity, drought tolerance, high } \\
\text { oil content, high yield }\end{array}$ & Desmae et al. (2015) \\
\hline ICIAR 19 BT & Samnut24 (Nigeria), ICIAR19BT (Niger) & $\begin{array}{l}\text { Early maturity, high yield, high oil } \\
\text { content, rosette disease resistance }\end{array}$ & Desmae et al. (2017) \\
\hline ICGV-98412 & Oboshie (Ghana), Babile-1 (Ethiopia) & $\begin{array}{l}\text { High yield, large seeded for } \\
\text { confectionery }\end{array}$ & Amare et al. (2016) \\
\hline $\begin{array}{l}\text { Mwenje and } \\
\text { Nyanda }\end{array}$ & - & $\begin{array}{l}\text { Resistant to aphids, Hilda and grain } \\
\text { moth }\end{array}$ & www.seedcogroup.com \\
\hline $\begin{array}{l}\text { ICGV-SM } \\
90704\end{array}$ & Serenut 2 (Uganda), Mamane (Mozambique) & $\begin{array}{l}\text { High yield, medium maturity, rosette } \\
\text { disease resistance }\end{array}$ & Kanyika et al. (2015) \\
\hline Harts & - & $\begin{array}{l}\text { Tolerant to early and late leaf spot, } \\
\text { high yielding }\end{array}$ & www.opot.co.za \\
\hline ARC-Oleic2 & - & High oleic acid content & www.opot.co.za \\
\hline ARC-Opal1 & - & Resistant to Botrytis stemrot & www.opot.co.za \\
\hline $\begin{array}{l}\text { ARC Sellie } \\
\text { Plus }\end{array}$ & - & $\begin{array}{l}\text { Low-oleic acid content, resistance to } \\
\text { podworm }\end{array}$ & www.opot.co.za \\
\hline Tufa & - & $\begin{array}{l}\text { Drought tolerant, intermediate oleic- } \\
\text { acid content }\end{array}$ & www.opot.co.za \\
\hline
\end{tabular}


Aflatoxin contamination caused by the fungus Aspergillus flavus and A. parasiticus is an important biotic factor affecting groundnut product quality and sustainable groundnut production in SSA (Waliyar et al. 1994; Monyo et al. 2012; Guchi 2015; Njoroge et al. 2017). It is also a potential threat to human and animal health globally (Waliyar et al. 2017). Further, aflatoxin contamination affects groundnut trade resulting in financial losses estimated at about US\$750 million per annum in SSA (Kamika and Takoy, 2011). Breeding for aflatoxin resistant groundnut genotypes is vital for human health and to enhance world trade (Waliyar et al. 2017). Some genetic resources developed by the International Crops Research Institute for Semi-Arid Tropics (ICRISAT) such as ICGV 87084, ICGV 87094, and ICGV 87110 are reportedly resistant to $A$. flavus. Furthermore, 12 groundnut accessions with resistance to aflatoxin are developed by the Agricultural Research Council in South Africa (Cilliers and Swanevelder 2003). Improved Spanish groundnut cultivars such as ICGV 91278, ICGV 91283, and ICGV 91284 were selected by ICRISAT showing considerable resistance for aflatoxin-producing fungus (Upadhyaya et al., 2001b). Groundnut accessions ICGs 13,603, 1415, $14,630,3584,5195,6703$ and 6888 were recommended for production for their low levels of aflatoxin content $\left(<4 \mu \mathrm{gg}^{-1}\right)$ which is far below the regulatory limits for EU $(4 \mu \mathrm{g} / \mathrm{kg})$, most developing countries $(10 \mu \mathrm{g} / \mathrm{kg})$, and the U.S.A. $(20 \mu \mathrm{g} / \mathrm{kg})$ (Magamba et al. 2017). Despite breeding progress, aflatoxin levels remain high in commercial groundnut products due to poor regulatory systems and other resource constraints. Effective post- and pre-harvest groundnut handling and processing are imperative to minimise aflatoxin contamination along the value chains of the crop (Magamba et al. 2017).

\section{Genetic resources for groundnut breeding}

\section{Gene banks}

Groundnut genetic resources are currently maintained at various gene banks and research institutions and programmes globally (Pandey et al. 2012; Desmae et al. 2017). The largest collection of groundnut accessions $(\sim 15,445)$ is held at ICRISAT gene bank in India (Pandey et al. 2012). Approximately $43 \%$ of groundnut collections at ICRISAT consists of landrace varieties, cultivars (7\%), breeding lines (31\%), and other genetic stocks (19\%) (e.g. mutants and experimental germplasm) (Upadhyaya et al. 2002).

In SSA, most of the groundnut germplasm have been obtained from ICRISAT's regional gene banks such as Niamey located in Niger and from the U.S.A. (Okello et al. 2010; Monyo and Varshney 2016). Further, some
SSA countries such as Malawi, Mali, Zimbabwe, Uganda and South Africa maintain groundnut genetic resources (Upadhyaya et al. 2001a; Okello et al. 2010) sourced from ICRISAT and U.S.A. In most cases, groundnut genetic resource held in various genebanks are available for research and breeding purposes subject to the signing of material transfer agreement. For example, in South Africa, almost all groundnut genetic resource held by the Agricultural Research Council are available on request (Cilliers and Swanevelder 2003). Groundnut genetic resource held by ICRISAT are also available by interested scientists for scientific studies or breeding purposes (Upadhyaya et al. 2001b). However, it is worth noting that material transfer can sometimes become more stringent especially if the germplasm has patent rights (Okello et al. 2010). Groundnut genetic resources currently held at various gene banks are sources of useful genes for the development of improved varieties with improved quality attributes and resistance to biotic and abiotic stress factors (Upadhyaya et al. 2005, 2014; Sharma et al. 2017a, 2017b).

\section{Synthetics and wild species to tap new alleles for groundnut breeding}

The primary gene pool of the cultivated groundnut is very narrow for some important characteristics such as resistance to foliar diseases (e.g. late leaf spot and rust) and insect pests (e.g. thrips) (Kumari et al. 2014; Favero et al. 2015; Michelotto 2017b). Wild species may offer wide variability, particularly for biotic and abiotic stress breeding (Sharma et al. 2017b). Utilisation of wild groundnut germplasm in breeding programmes has been restricted by reproductive barriers between wild and cultivated species. This presented technical difficulties in making large numbers of crosses due to ploidy differences between the two species (Kumari et al. 2014). Successful crosses between wild and cultivated species can be achieved through the development of synthetic groundnut (i.e. doubling of chromosome number of the hybrid which is developed from two diploid wild species) (Sharma et al. 2017b). Several amphidiploid and autotetraploid groundnuts have been developed using A- and B-genome accessions with high levels of resistance to multiple stresses (e.g. late leaf spot, stem rot and collar rot diseases) (Sharma et al. 2017b). Wild species such as A. batizocoi, $A$. gregoryi, and $A$. magna can be used as female parents and many A-genome species can be used as male parents to introgress desirable genes into the cultivated groundnut (Favero et al. 2015). Amphidiploid and autotetraploid groundnut have been developed by ICRISAT (Table 2) which serve as useful genetic resource 
Table 2. List of synthetic tetraploid groundnuts developed at ICRISAT.

\begin{tabular}{|c|c|c|c|c|c|}
\hline Sr. No. & Code & Origin & Species & Genome & References \\
\hline 1 & ISATGR 1212 & Synthetic amphidiploid & A. duranenesis $\times$ A. ipaensis & $A B$ & Shilpa et al. (2013), Mallikarjuna et al. (2011) \\
\hline 2 & ISATGR 11A & Synthetic autotetraploid & A. magna $\times$ A. valida & $B B$ & Shilpa et al. (2013), Mallikarjuna et al. (2011) \\
\hline 3 & ISATGR 5B & Synthetic autotetraploid & A. magna $\times$ A. batizocoi & $B B$ & Shilpa et al. (2013), Mallikarjuna et al. (2011) \\
\hline 4 & ISATGR 9A & Synthetic amphidiploid & A. batizocoi $\times$ A. cardenasii & BA & Shilpa et al. (2013), Mallikarjuna et al. (2011) \\
\hline 5 & ISATGR 11A & Synthetic autotetraploid & A. magna $\times$ A. valida & BB & Shilpa et al. (2013), Mallikarjuna et al. (2011) \\
\hline 6 & ISATGR 40A & Synthetic amphidiploid & A. ipaensis $\times$ A. duranensis & BA & Shilpa et al. (2013), Mallikarjuna et al. (2011) \\
\hline 7 & ISATGR 90B & Synthetic autotetraploid & A. kempff-mercadoi $x$ A. stenosperma & AA & Shilpa et al. (2013), Mallikarjuna et al. (2011) \\
\hline 8 & ISATGR 155 & Autotetraploid & A. diogoi $\times$ A. cardenasii & $A A$ & Shilpa et al. (2013), Mallikarjuna et al. (2011) \\
\hline 9 & ISATGR 168B & Synthetic amphidiploid & A. valida $\times$ A. duranensis & $B A$ & Shilpa et al. (2013), Mallikarjuna et al. (2011) \\
\hline 10 & ISATGR 278-18 & Synthetic amphidiploid & A. duranensis $x$ A. batizocoi & $A B$ & Shilpa et al. (2013), Mallikarjuna et al. (2011) \\
\hline 11 & ISATGR 265-5 & Synthetic amphidiploid & A. kempff-mercadoi x A. hoehnei & $B A$ & Shilpa et al. (2013), Mallikarjuna et al. (2011) \\
\hline 12 & ISATGR 268-5 & Synthetic amphidiploid & A. batizocoi $\times$ A. cardenasii & $B A$ & Shilpa et al. (2013), Mallikarjuna et al. (2011) \\
\hline 13 & ISATGR 10B & Synthetic autotetraploid & A. magna $\times$ A. valida & $B B$ & Shilpa et al. (2013), Mallikarjuna et al. (2011) \\
\hline 14 & ISATGR 35A & Synthetic amphidiploid & A. batizocoi $\times$ A. duranensis & $B A$ & Shilpa et al. (2013), Mallikarjuna et al. (2011) \\
\hline 15 & ISATGR 206B & Synthetic amphidiploid & A. duranensis $\times$ A. valida & $A B$ & Shilpa et al. (2013), Mallikarjuna et al. (2011) \\
\hline 16 & ISATGR 91A & Synthetic autotetraploid & A. duranensis $\times A$. cardenasii & $A A$ & Shilpa et al. (2013), Mallikarjuna et al. (2011) \\
\hline 17 & ISATGR 154 & Synthetic amphidiploid & A. valida $\times$ A. duranensis & $B A$ & Shilpa et al. (2013), Mallikarjuna et al. (2011) \\
\hline 18 & ISATGR 48B & Synthetic amphidiploid & A. valida $\times A$. duranensis & $B A$ & Shilpa et al. (2013), Mallikarjuna et al. (2011) \\
\hline
\end{tabular}

to transfer useful genes into the cultivated groundnut (Mallikarjuna et al. 2011; Michelotto et al. 2016). Leaf rust and late leaf spot resistance were successfully introgressed into the cultivated groundnut varieties (e.g. ICGV 91114, ICGS 76, ICGV 91278, JL 24, and DH 86) using two synthetic resistance sources namely: ISATGR 278-18 and ISATGR 5B (Kumari et al. 2014). Resistance to thrips was introgressed into cultivated groundnut cultivars using amphidiploid species such as $A$. batizocoi $x A$. kempffmercadoi, A. gregoryi $x$ A. stenosperma, and A. magna $x$ A. cardenasii (Michelotto et al. 2017). Introgression of root-rot nematode resistance gene $(\mathrm{Rma})$ into tetraploid groundnut from synthetic allotetraploid donor (TxAG6) has been widely practiced in modern cultivars (Nagy et al. 2010). Chromosome pairing, pollen and pod fertility analysis in hybrids between $A$. hypogaea and A. amphidiploids revealed that amphidiploids can be used as a genetic bridge for the transfer of genes from wild species to the cultivated groundnut (Singh 1986). Tetraploid $(2 \mathrm{n}=4 \mathrm{x}=40)$ peanut (Arachis hypogaea L. subsp. hypogaea var. hypogaea) lines GP-NC WS 16 and GP-NC WS 17 (SPT 06-07) with resistance to multiple diseases including early leaf spot (ELS), Cylindrocladium black rot, Sclerotinia blight, and tomato spotted wilt were derived from interspecific hybridisation from the diploid $(2 n=2 x=20)$ wild species, $A$. cardenasii (Tallury et al. 2014). In general, the limited level of resistance for economically important traits such as resistance to leaf spot and rust in cultivated groundnut cultivars can be enhanced through the development of synthetic groundnuts. Recombination of cultivated and wild groundnut germplasm will likely improve agronomic, physiological and quality attributes resulting in the development of superior genotypes with resistance to biotic and abiotic stress factors to boost production in SSA.

\section{Landraces and modern groundnut varieties}

Landraces are a valuable source of genetic diversity and possess useful traits for breeding (Lopes et al. 2015; Corrado and Rao 2017). Landraces can be introduced in groundnut breeding programmes to incorporate unique genes such as resistance to biotic and abiotic stresses; and quality attributes. Significant genetic variation for quality attributes such as oil, zinc and iron contents exist among groundnut landrace varieties (Asibuo et al. 2008). Bolivian landraces of groundnut revealed larger diversity with respect to seed colour, seed size, seed weight, oleic and linoleic acid contents; and showing moderate to high level of resistance to late leaf spot (Husain and Mallikarjuna 2012). Mexican hirsuta groundnut landraces such as PI576633, PI576634, PI576635, PI576636, PI576637 and PI576638 were also identified to be superior in flavour and quality (Sanchez-Dominguez and Williams 1993). Many other sources of resistance to foliar diseases such as rust and late leaf spot were identified from South American landrace varieties (Singh and Nigam 2016). Several pure lines such as 48-7, 48-14, 48-15A, 48-21, 48-34, 48$35,48-36,48-37,48-44,48-45$ and $48-70 A$ with resistance to groundnut rosette disease were selections from landraces (Singh and Nigam 2016). In pigeon pea and chickpea, landraces or their selections were released directly as cultivated varieties (Asthana et al. 1996; Remanadan 1996). Some cowpea landrace varieties were released for commercial production in India (Sharma 1996). Landrace varieties are rarely used in breeding programmes despite possessing useful attributes. Collection and strategic conservation of groundnut landrace varieties and their exploitation in breeding programmes will aid identification of useful genes/traits for breeding for improved grain yield, quality attributes, biotic and 
abiotic stress tolerance. Groundnut landrace varieties may also be useful for genetic mapping studies to unravel genetic control underlying of important traits (Varshney et al. 2013).

\section{Breeding methods of groundnut}

Groundnut improvement and cultivar development in SSA mainly depended on conventional breeding including pure line selection, mass selection, pedigree breeding and backcross breeding methods (Okello et al. 2010; Janila et al. 2013). For example, Serenut 5R a high yielding, early maturing, resistant to groundnut rosette disease and late leaf spot was released in Uganda using bulk selection (Table 3). Babile-1 with the accession number ICGV-98412, released in Ghana and Ethiopia, is high yielding, medium maturing and moderately resistant to late leaf spot. It was bred at the International Crop Research Institute for Semi-Arid Tropics, Patancheru, India (Table 3).

Genetic variability available in cultivated and wild Arachis have been extensively exploited through conventional breeding to develop improved varieties (Singh and Nigam 2016; Sharma et al. 2017b). Genetic variation for important traits such as plant height, number of primary branches per plant, number of mature and immature pods per plant, kernel yield per plant, hundred seed weight, haulm yield per plant and dry pod yield per plant have been reported in groundnut. This is useful for phenotypic analysis and breeding in this crop (Kushwah et al. 2017; Hampannavar et al. 2018). Further, traits like plant height, pods per plant, 100-pods weight, shelling percentage, harvest index and pod yield per plant have high heritability and considerably higher genetic advance (Nath and Alam 2002; HajHussein et al. 2018). High heritability estimate and genetic advance is an indication that variation is attributable to a high degree of genetic effect and selection can be effective (Johnson et al. 1955).

Knowledge on the degree of association between yield contributing characters and yield is very essential for the development of high yielding genotypes in groundnut. Correlation studies provide an opportunity to study the magnitude and direction of association of yield with its components traits and also among various yield-related components (Faye et al. 2015; Mhlaba et al. 2018). Groundnut pod yield per plant exhibited significant positive correlation with grain yield per plant, number of kernel per plant, hundred kernel weight, number of pods per plant, harvest index and shelling percentage (Kushwah et al. 2017; Zongo et al. 2017a; Hampannavar et al. 2018). This information could help in formulating effective selection criteria in groundnut improvement programme for genetic improvement for grain yield.

In general, groundnut breeding in SSA is mostly dependent on limited selection in segregating generations resulting in low selection efficiencies. Consequently, a limited number of improved groundnut genotypes were developed and deployed. In addition, the conventional breeding requires extended time to develop varieties. It also depends on the screening of a large number of breeding populations under multilocation trials due to the high genotype and environment interaction effect (Ngirazi et al. 2015; Kebede and Getahun 2017). Therefore, the integration of new breeding tools such as molecular markers and marker-assisted selection in groundnut breeding programmes could enhance the precision and speedy development of improved groundnut cultivars.

\section{New and emerging tools for groundnut breeding}

\section{High-throughput automated phenotyping techniques}

Plant phenotypic data collection with sufficient resolution and accuracy remains a major limiting factor for the effective use of genomic data for crop improvement (Bai et al. 2016). In developing countries where groundnut yield is low, the breeding focus is to improve yield and tolerance to biotic and abiotic stress factors. Selection of groundnut genotypes using pod yield has been slow and yielded highly variable results as yield is affected by genotype by environment interactions (Luis et al. 2016), which causes difficulties in selecting genotypes with wide adaptation resulting in delayed cultivar release.

Crop breeding strategies for higher yield and disease tolerance can be accelerated through the use of highthroughput phenotyping (Shakoor et al. 2017). Instead of using high-throughput phenotyping tools directly in breeding programmes, they may be more useful to enhance the efficiency of genomic tools during the establishment of marker-trait associations, genomewide associations and training genomic selection models (Janila et al. 2016). Patrick et al. (2017) reported a rapid screening of tomato spot wilt disease resistance among twenty genotypes of groundnuts through the application of high-throughput phenotyping tool. High throughput phenotyping for total oil content in groundnut kernel through the application of near infrared spectrometry (NIRS) system was determined as reproducible, robust, rapid, cost-effective, and non-destructive, and can be used in conjunction with high oleic fatty acid 
Table 3. List of improved groundnut varieties with resistance to biotic and abiotic stress tolerance and desirable agronomic attributes reported globally.

\begin{tabular}{|c|c|c|c|c|c|c|}
\hline Name & Pedigree & Traits & Country & Organisation & $\begin{array}{l}\text { Year of } \\
\text { release }\end{array}$ & References \\
\hline NuMex 01 & $\begin{array}{l}\text { NM Valencia A x } \\
\text { Brantley }\end{array}$ & High oleic content & U.S.A. & $\begin{array}{l}\text { New Mexico Agricultural State } \\
\text { University }\end{array}$ & 2013 & $\begin{array}{l}\text { Puppala and } \\
\text { Tallury (2014) }\end{array}$ \\
\hline NemaTAM & $\begin{array}{l}\text { A.cardenasii Krapov. } \\
\text { and W.C. Gregory x } \\
\text { A. diogoi Hoehne }\end{array}$ & Resistant to root-knot nematode & U.S.A. & $\begin{array}{l}\text { Texas Agricultural Experiment } \\
\text { Station }\end{array}$ & 2002 & $\begin{array}{l}\text { Simpson et al. } \\
\text { (2003) }\end{array}$ \\
\hline C724-19-15 & C-99R X COAN & $\begin{array}{l}\text { Resistant to root-knot nematode } \\
\text { and tomato spotted wilt } \\
\text { tospovirus }\end{array}$ & U.S.A. & $\begin{array}{l}\text { USDA-ARS and Georgia } \\
\text { Agricultural Experiment Station }\end{array}$ & 2008 & $\begin{array}{l}\text { Holbrook et al. } \\
\text { (2008) }\end{array}$ \\
\hline Tifguard & C-99R X COAN & $\begin{array}{l}\text { Resistant to root-knot nematode } \\
\text { and tomato spotted wilt } \\
\text { tospovirus }\end{array}$ & U.S.A. & $\begin{array}{l}\text { University of Georgia Coastal Plain } \\
\text { Experiment Station }\end{array}$ & 2007 & $\begin{array}{l}\text { Holbrook et al. } \\
\text { (2008) }\end{array}$ \\
\hline TifGP-2 & & $\begin{array}{l}\text { Resistant to root-knot nematode } \\
\text { and tomato spotted wilt } \\
\text { tospovirus }\end{array}$ & U.S.A. & $\begin{array}{l}\text { USDA-ARS and Georgia } \\
\text { Agricultural Experiment Station }\end{array}$ & 2010 & $\begin{array}{l}\text { Holbrook et al. } \\
\text { (2012) }\end{array}$ \\
\hline ICGV-91114 & $\begin{array}{l}\text { ICGV } 86055 \times \text { ICGV } \\
86533\end{array}$ & Tolerant to rust and drought & India & ICRISAT & 2006 & ICRSAT (2012) \\
\hline "Webb" peanut & PI 667551 & $\begin{array}{l}\text { High-yielding, high-oleic fatty } \\
\text { acid, nematode resistant }\end{array}$ & U.S.A. & Texas AgriLife Research & 2001 & $\begin{array}{l}\text { Simpson et al. } \\
\text { (2013) }\end{array}$ \\
\hline TG-37A & TG-25 $\mathrm{X}$ variety TG-26 & $\begin{array}{l}\text { Mutant with semi-dwarfness, } \\
\text { compact pod setting, high yield } \\
\text { and smooth pod surface }\end{array}$ & India & $\begin{array}{l}\text { Central Sub-Committee on Crop } \\
\text { Standards, Release and } \\
\text { Notification of Varieties, Ministry } \\
\text { of Agriculture }\end{array}$ & 2004 & $\begin{array}{l}\text { Kale et al. } \\
\text { (2004) }\end{array}$ \\
\hline Golden & Mutant & $\begin{array}{l}\text { Mutant with high yielding and } \\
\text { Cercospora leaf spot resistant }\end{array}$ & India & $\begin{array}{l}\text { Barani Agricultural Research } \\
\text { Institute (BARI) }\end{array}$ & 2002 & $\begin{array}{l}\text { Naeem-UD-Din } \\
\text { et al. (2009) }\end{array}$ \\
\hline $\begin{array}{l}\text { Binachinabadam- } \\
\quad 5\end{array}$ & $M 6 / 250 / 54-20$ & Mutant with salinity tolerance & & $\begin{array}{l}\text { Bangladesh Institute of Nuclear } \\
\text { Agriculture }\end{array}$ & 2011 & $\begin{array}{l}\text { Azad et al. } \\
\text { (2014) }\end{array}$ \\
\hline Huayu 22 & & $\begin{array}{l}\text { Mutant with high yield, good } \\
\text { quality, several diseases } \\
\text { resistance, drought tolerant } \\
\text { and wide adaptable }\end{array}$ & China & $\begin{array}{l}\text { Shandong Peanut Research } \\
\text { Institute }\end{array}$ & 2003 & Wu et al. (2006) \\
\hline Serenut 5R & ICGM 522 X RG 1 & $\begin{array}{l}\text { High yielding, early maturing, } \\
\text { resistant to groundnut rosette } \\
\text { disease } \\
\text { resistant to late leaf spot }\end{array}$ & Uganda & $\begin{array}{l}\text { National Semi-Arid Resources } \\
\text { Research Institute }\end{array}$ & 2010 & $\begin{array}{l}\text { Okello et al. } \\
\text { (2016) }\end{array}$ \\
\hline CG-8 & ICGV-SM 08501, & - & Malawi & ICRISAT & 2014 & $\begin{array}{l}\text { Setimela et al. } \\
\text { (2017) }\end{array}$ \\
\hline CG-9 & ICGV-SM 08503 & - & Malawi & ICRISAT & 2014 & $\begin{array}{l}\text { Setimela et al. } \\
\text { (2017) }\end{array}$ \\
\hline CG-10 & ICGV-SM 01724 & - & Malawi & ICRISAT & 2014 & $\begin{array}{l}\text { Setimela et al. } \\
\text { (2017) }\end{array}$ \\
\hline CG-11 & ICGV-SM 01731 & - & Malawi & ICRISAT & 2014 & $\begin{array}{l}\text { Setimela et al. } \\
\text { (2017) }\end{array}$ \\
\hline CG-13 & ICGV-SM 99551 & Short duration & Malawi & ICRISAT & 2014 & $\begin{array}{l}\text { Setimela et al. } \\
\text { (2017) }\end{array}$ \\
\hline CG-14 & ICGV-SM 99556 & - & Malawi & ICRISAT & 2014 & $\begin{array}{l}\text { Setimela et al. } \\
\text { (2017) }\end{array}$ \\
\hline CG-12 & ICGV-SM 01514 & - & Malawi & ICRISAT & 2014 & $\begin{array}{l}\text { Setimela et al. } \\
\text { (2017) }\end{array}$ \\
\hline NARINUT 2015 & ICGV-SM 01731 & Rosette disease tolerant & Tanzania & ICRISAT & 2015 & $\begin{array}{l}\text { Setimela et al. } \\
\text { (2017) }\end{array}$ \\
\hline KUCHELE 2015 & ICG 8326 & & Tanzania & ICRISAT & 2015 & $\begin{array}{l}\text { Setimela et al. } \\
\text { (2017) }\end{array}$ \\
\hline NACHI 2015 & ICGV-SM 90704 & - & Tanzania & ICRISAT & 2015 & $\begin{array}{l}\text { Setimela et al. } \\
\text { (2017) }\end{array}$ \\
\hline Serenut 6T & $\begin{array}{l}\text { ICGV } 93437 \times \text { ICGV-SM } \\
\quad 93561\end{array}$ & $\begin{array}{l}\text { High-yielding, early maturing } \\
\text { and resistant to groundnut } \\
\text { rosette disease }\end{array}$ & Uganda & $\begin{array}{l}\text { National Semi-Arid Resources } \\
\text { Research Institute }\end{array}$ & 2010 & $\begin{array}{l}\text { Okello et al. } \\
\text { (2018) }\end{array}$ \\
\hline ICGV 91278 & JL 24'/UF 71513-1 & Aflatoxin resistant & India & ICRISAT & 1999 & $\begin{array}{l}\text { Upadhyaya } \\
\text { et al. (2001b) }\end{array}$ \\
\hline ICGV 9128 & U 4-7-5/JL 24 & Aflatoxin resistant & India & ICRISAT & 1999 & $\begin{array}{l}\text { Upadhyaya } \\
\text { et al. (2001b) }\end{array}$ \\
\hline ICGV 91284 & J 11'/ICGV 86184 & Aflatoxin resistant & India & ICRISAT & 1999 & $\begin{array}{l}\text { Upadhyaya } \\
\text { et al. (2001b) }\end{array}$ \\
\hline
\end{tabular}

screening to provide for simultaneous phenotyping of total oil and high oleic acid contents (Sundaram et al. 2010; Awada et al. 2018). Adoption of high-throughput automated technologies is hypothesised to result in faster development of well-adapted and high-performing cultivars (Awada et al. 2018). However, the 
application of high-throughput phenotyping techniques in genetic improvement of groundnut and other crops are still very limited. This is probably because automated phenotyping is an emerging breeding approach and has not yet been adopted by plant breeders and crop improvement programmes (Awada et al. 2018).

\section{Genomic tools}

\section{Marker-assisted selection}

Molecular breeding refers to the technique of using DNA markers that are tightly linked to phenotypic traits to assist in a selection scheme for a particular breeding objective (Jaradat 2016). Molecular markers and genetic linkage maps are pre-requisites for molecular breeding (Varshney et al. 2009). Marker-assisted selection (MAS) refers to the selection of superior genotypes using molecular markers (Kumpatla 2012). Compared with conventional phenotypic selection, MAS is not influenced by environmental conditions because it detects the structural polymorphisms at the molecular level. Further MAS is cheaper and less labour intensive, allows selection in off-season nurseries and has a potential to accelerate the breeding process (Kumpatla 2012).

Due to low levels of molecular polymorphism among cultivated groundnut varieties, MAS in groundnut has not been used extensively compared with other major crops (Burow et al. 2013). Similarly, a low level of variability in cultivated groundnut have been reported using molecular markers (Bhagwat et al. 1997). The cultivated groundnut has been analysed by several marker systems such as Restriction Fragment Length Polymorphism (RFLP), Random Amplified Polymorphic DNA (RAPD), Amplified Fragment Length Polymorphism (AFLP), Single Nucleotide Polymorphism (SNPs) and Simple Sequence Repeat markers (SSR) (Stalker and Mozingo 2001; Zhao et al. 2016). Currently, SSR markers are commonly used in groundnut genetic analysis and breeding due to their co-dominance, simplicity, high polymorphism, repeatability, multi-allelic nature and transferability within the genus Arachis (He et al. 2003; Pandey et al. 2012; Wang et al. 2018). Mondal et al. (2012) identified three and four SSR alleles which were found associated with rust and late leaf spot resistance in groundnut, respectively. About 376 highly informative SSR markers linked to resistance to early leaf spot, groundnut rosette disease, and rust and aflatoxin contamination across African cultivated groundnut varieties were identified useful to identify suitable parents for mapping populations or breeding (Kanyika et al. 2015). There is approximately 14392 publicly available SSR markers in the A. hypogeae database (Wang et al. 2018). Recently, about 210 new SSRs were developed for A. hypogaea useful for genetic diversity analysis and cultivar development (Wang et al. 2018). In addition, SSR markers have been developed specifically for different Arachis species such as $A$. duranensis A. paensis and A. stenosperma (Zhao et al. 2012).

Table 4 lists some molecular markers developed for groundnut breeding. Four SSR markers (e.g. IPAHM103, GM2079, GM1536 and GM2301) associated with groundnut leaf rust resistance were identified by Varshney et al. (2014). SSR markers pPGPseq-17F6, pPGPseq-2F05, pPGPseq-8E12, pPGPseq-13A10 and pPGPseq-16C6 are reportedly well-associated with rust resistance (Shoba et al. 2012). Zongo et al. (2017b) identified marker GM1911 associated to early leaf spot resistance in groundnut. Further, SSR markers such as pPGPseq2B10, pPGPseq-2F05, Ppgp13A7, PM 3751 62 , pPGPseq5D5 ${ }_{220}$ and PM384 100 are also linked to late leaf resistance (Mace et al. 2006; Shoba et al. 2012). SSR markers such as SSR_F149451, Cer14, pPGP-seq2H08, SSR_DX508223 and SSR_FI500754 linked to plant growth habit and SSR markers PM50, SSR GW391728, SSR G0340377 and PPGP_seq2H08 linked seed size have been identified in groundnut. Two transposable element markers namely: TE 360 and TE 498, were found to be linked to rust resistance gene (Mondal et al. 2014). SSR marker GM 1991 is reportedly linked to a drought tolerant QTL in groundnut (Guo et al. 2012). Chu et al. (2007) identified marker S197 as a reliable predictor for nematode resistance.

Other molecular tools such as diversity arrays technology (DArT) are useful in groundnut improvement programmes. Shasidhar et al. (2017) developed two genetic maps based on the DArT and diversity arrays technology sequencing (DArTseq) markers and identified genomic regions linked to groundnut oil content and fatty acids. However, genetic studies revealed low polymorphism and the moderate level of genetic diversity among diploid and tetraploid groundnut genetic pool (Varshney et al. 2010) indicating utilisation of DArT marker system may limit efficient genetic analysis of groundnut genetic resources for cultivar development (Pandey et al. 2012). Development of highly discriminative and informative DArT markers is useful for genetic analysis and breeding in groundnut.

MAS helps to develop ideal groundnut cultivar with inbuilt resistance and improved pod and kernel features (Mothilal 2012). Introgression of nematode resistance through an amphidiploid pathway into cultivated groundnut was successfully implemented using MAS and subsequently nematode resistant groundnut cultivar, NemaTAM was developed (Holbrook et al. 2011). 
Table 4. Some molecular marker systems developed for genetic analysis and breeding in groundnut.

\begin{tabular}{|c|c|c|c|c|}
\hline \multirow[b]{2}{*}{ Marker name } & \multirow[b]{2}{*}{ Marker type } & \multicolumn{3}{|c|}{ Marker sequence } \\
\hline & & Forward primer & Reverse primer & References \\
\hline IPAHM103 & SSR & GCATTCACCACCATAGTCCA & TCСTCTGACTTTCСТCСАTCA & Varshney et al. (2014) \\
\hline GM1536 & SSR & AAAGCCCTGAAAAGAAAGCAG & ATGCATTTGCAGGTTCTGGT & Varshney et al. (2014) \\
\hline GM2301 & SSR & GTAACCACAGCTGGCATGAAC & CTTCAAGAACCCACCAACAC & Varshney et al. (2014) \\
\hline GM2079 & SSR & GGCCAAGGAGAAGAAGAAAGA & GAAGGAGTAGTGGTGCTGCTG & Varshney et al. (2014) \\
\hline GM1991 & SSR & GAAAATGATGCCGAGAAATGT & GGGGAGAGATGCAGAAAGAGA & Guo et al. (2012) \\
\hline GM 1911 & SSR & CAGCTTTCTTTCAATTCATCCA & CACTTCGTGTTCTTCCTGCTC & Guo et al. (2012) \\
\hline TE 360 & TEM & GGATATGATGCCCATAGCTGA & TGCTGACTACTTGCAATGCC & Mondal et al. (2014) \\
\hline TE 498 & TEM & ATGACTTACATGTAGCAATTG & TGAAAGGAGTCAAAGGTCATG & Mondal et al. (2014) \\
\hline S197 & RAPD & CTGTCGAACCATGGAAGAAGATCC & CCAACTTGATGGTAGAAGTATGCTT & Chu et al. (2007) \\
\hline AHCW0061 & SSR & TCATGTGAATTTGTGGACGGT & CCAGGTTITTGAGGTCCCTGA & Wang et al. (2018) \\
\hline AHCW0310 & SSR & GTTCAAGGGCTGTGCATTGG & GGGTTCGACTCCCGTCTTAT & Wang et al. (2018) \\
\hline AHCW0545 & SSR & ACAGAAGAAGAAACAGCGCG & TTCCGTCATGTGCTTCGGAA & Wang et al. (2018) \\
\hline AHCW0618 & SSR & AAATTTGAGCACGCATCCCC & TGTCTITTCCTCGCCTTTGT & Wang et al. (2018) \\
\hline AHCW0700 & SSR & TGGAAGTTTCACGGGACAGG & GTAGCAAGCTTCCCCACCAT & Wang et al. (2018) \\
\hline AHCW0768 & SSR & GGACCCATTITTGCAAGAGAGA & CGGATTGCAACATTGGCGAA & Wang et al. (2018) \\
\hline AHCW1250 & SSR & ACAGCTGCCTCTTCTCTGTG & CCCACTCAAAATCGGATTTGGA & Wang et al. (2018) \\
\hline AHCW1510 & SSR & TCCTGCACCATGACCATGAA & TGTTCGGCACCAATCTGTCA & Wang et al. (2018) \\
\hline AHCW1765 & SSR & CGCTGGTCTGGCATTTAACG & AAGGGAGGAGGAGTTGGGTT & Wang et al. (2018) \\
\hline AHCW1862 & SSR & TGTCAGGGATGTGTTTGGACT & GGGCAAGCTCTTTAAACTGCA & Wang et al. (2018) \\
\hline Cer14 & SSR & AGCTGCTTTGACCAGCCGGG & CGCAAGCTTCCTTGTAGATGGTGGT & Mondal et al. (2012) \\
\hline SSR_DX508223 & SSR & GGATTAGGGTTATGAGTTAGGAAACAC & GCTGATGATTGGTTCGGGTAT & Bhad et al. (2016) \\
\hline SSR_FI500754 & SSR & AAGTGGCAGAATCACAGATGG & AGGGTAGAGGTTGGAGAGAAGG & Bhad et al. (2016) \\
\hline SSR_FI499451 & SSR & GTAAGCCACTCTATCACCCCAG & ACAGCCTCACAAATCCAAGAAT & Bhad et al. (2016) \\
\hline pPGPseq_2H08 & SSR & TAAGTGGGGTGGGAGTGGAC & AGCAGTTTGCGTAAGCATTTG & Ferguson et al. (2004) \\
\hline RGC 24 & SSR & TाTGACGGTATGTGCTTTCTTG & TGCCACGACCAAACCAATC & Bhad et al. (2016) \\
\hline PM 50 & SSR & САATTCATGATAGTATTTATTGGACA & CTTTCTCCTCCССАATTGA & Bhad et al. (2016) \\
\hline SSR_GW391728 & SSR & TCATCATCTGCTAGGGTTATGG & GGTTCCACCTCTTGTCCAGTAT & Mondal et al. (2012) \\
\hline
\end{tabular}

$S S R$, simple sequence repeat markers, TEM, Transposable element markers, RAPD, Random Amplified Polymorphic DNA

Marker-assisted backcrossing (MABC) has been commonly used in groundnut improvement, for instance, high oleic acid content and nematode resistant variety, 'Tifguard' was developed through the application of this technique (Tiwari et al. 2017). Introgression of rust resistance from 'GPBD 4' groundnut cultivar into susceptible varieties ICGV 91114, JL 24 and TAG 24 were employed through $\mathrm{MABC}$ which resulted in the development of improved rust resistance groundnut lines (Varshney et al. 2014).

In developing countries including SSA, application of MAS in groundnut improvement is very limited. This is mainly due to the lack of human capital and infrastructure (Janila et al. 2016). However, some successes have been reported. For example, high oleic acid content governing genes, $a h F A D 2 A$ and $a h F A D 2 B$, were transferred from high-oleic parents (UF-85, Guat and Atete) to lowoleic commercially produced South African cultivars (e.g. Akwa, Kwarts and Harts) through the application of MAS (Mienie and Pretorius 2013). AFPL markers linked to resistance to groundnut rosette disease were successfully identified and mapped in South Africa (Herselman et al. 2004). In Malawi, two groundnut genotypes, RG1 and ICG 1291, were identified as resistant to groundnut rosette disease using SSR markers (Chintu 2013). Selected advanced groundnut lines with different phenotypic attributes were characterised at the molecular level using SSR markers in Ghana (Oteng-Frimpong et al. 2015). Integration of MAS into groundnut breeding programmes in SSA will have greater implication on groundnut improvement in the future.

Marker-assisted backcrossing is routinely applied in breeding programmes for gene introgression (Frisch and Melchinger 2005). MABC aims to transfer one or a few genes/QTLs of interest from agronomically inferior (donor parent) into a superior cultivar or elite breeding line (serving as the recurrent parent) to improve the targeted trait (Jiang, 2013). MABC was used to develop foliar fungal disease resistant lines (Varsheney et al. 2014; Janila et al. 2016) and high oleic lines in Spanish and Virginia bunch types (Janila et al. 2016). However, MABC is not the best approach to develop commercial varieties as compared to MAS which allows improvement of other desirable traits in addition to the target trait selects using markers.

MAS and MABC are not well-suited for analysis of quantitative traits (Sorrells 2015). In such cases, genomic selection is a promising breeding strategy for rapid improvement of quantitative traits. Genomic selection (GS) relies on the development of selection models based on dense genetic markers distributed across the whole genome and phenotyping of a training population for selection of individuals with high genome-estimated breeding values in the breeding population (Resende et al. 2012). GS can therefore provide effective selection using polygenic traits with low heritability (Sun 2014).

In general, MAS has been useful in groundnut breeding. However, in order to develop sufficient genomic 
resources for groundnut, MAS has to be widely applied to identify markers linked to other important traits such as drought tolerance and aphid (Aphis craccivora) resistance which are becoming a major bottleneck for groundnut production in SSA. Thus, integration of MAS into groundnut breeding programmes in the region will have greater implication on groundnut improvement in the future. In general, molecular markers developed specifically for groundnut provide opportunities to characterise groundnut genetic resources for biotic stress and abiotic stress constraints, agronomic attributes and grain quality traits. This will result in identification and selection of genetically unrelated genotypes possessing key attributes for strategic crossing to develop highyielding genotypes with key farmer preferred traits and also for industrial purposes (Pandey et al. 2012). Further, to accelerate cultivar development in SSA, access to research funding and technology especially genomic tools will aid mapping of the groundnut genetic pool for accelerated selection and breeding.

\section{Next generation sequencing (NGS)}

NGS technologies are highly dependent on massive parallel sequencing, high resolution imaging, and complex algorithms to deconvolute signal data to generate sequence data. NGS technologies offer a wide variety of applications such as whole genome de novo and resequencing, transcriptome sequencing (RNA-seq), microRNA sequencing, amplicon sequencing, targeted sequencing, chromatin immuno precipitated DNA sequencing (ChIP-seq), and methylome sequencing (Kumpatla et al. 2012). Genotyping- by-sequencing and whole-genome resequencing, can lead to the development of molecular markers suited to studies of genetic relationships among breeding materials, genetic mapping of target genes and genome-wide association studies. This can facilitate the selection of individuals with resistant to climatic stress and to pathogens causing substantial losses in agriculture (David and Repkova 2017). NGS technology has been applied for the identification of genes related to resistance to biotic stress in wild groundnut relatives (Brasileiro et al. 2014). For example, quantitative trait loci (QTLs) linked to leaf spot resistance were identified in groundnut through SNP-based next generation sequencing (Liang et al. 2017). Three different viruses from three families of forage groundnut (A. pintoi) were identified through the application of NGS (Sanchez et al. 2016). Complete chloroplast genome sequences of seven Arachis species were generated using NGS sequencing (Yin et al. 2017). The genetic relationship among groundnut genotypes can also be studied using NGS. In general, inclusion of NGS in groundnut breeding programmes in SSA which currently relies mostly on conventional breeding methods will assist in rapid development of genomic tools for groundnut improvement and cultivar development.

\section{Mutation breeding in groundnut}

Groundnut has narrow genetic base because of its monophyletic origin, limited gene flow due to ploidy barrier and self-pollination (Yusuf et al. 2017). Mutation breeding serves as an alternative approach to conventional plant breeding to increase genetic variability and could confer specific improvement without significantly altering phenotype expression (Kulthe and Kothekar 2011). Physical mutagens such as $X$-ray, gamma rays, $\beta$-rays, fast neutrons and chemical mutagens like, ethyl methane sulphonate, ethidium bromide, acryflavine, diethyl methane sulphonate (DES), N- nitroso- $\mathrm{N}$ - methyl - urea, Nethyl-Nnitroso-urea, ethylene imine and sodium azide have been successfully used to create genetic variability in groundnut (Kumari 2008; Bhagwan and Akkiraju 2015; Gunasekaran and Pavadai 2015; Habtamu 2016).

About 72 groundnut varieties have been developed through mutation breeding (Janila et al. 2013). Table 3 lists some improved groundnut varieties with resistance to biotic (e.g. leaf spot and aflatoxin) and abiotic stress (e.g. drought and salinity) tolerance and improved quality attributes (e.g. increased seed size, high oleic to linoleic ratio). Several of these varieties were developed using mutation breeding. For example, TG-37A and Golden groundnut mutants were developed and released in India. TG-37A is a semi-dwarf, compact pod setting, high yielding and with smooth pod surface, while variety Golden is high yielding and Cercospora leaf spot resistant. Mutants such as Huayu 22 and $\mathrm{Fu}$ 22, were released in China. Huayu 22 is high yielding, high quality and resistant to several diseases and with wide adaptation. Mutant variety Fu 22 is known for its tolerance against $A$. flavus (Maluszynski 2001).

Groundnut varieties with high oleic to linoleic acid ratio have become preferred by the groundnut industry due to their increased shelf life and improved health benefits (Chamberlin et al. 2011). Mondal and Badigannavar (2013) reported a groundnut mutant variety with $78 \%$ improvement in oleic acid content compared with its parental genotype. Similarly, Nadaf et al. (2009) reported high oleic to linoleic acid ratio in selected groundnut mutants. The first high oleic groundnut variety released in the world was SunOleic 95R, which was derived from a cross between a high oleic breeding line F435 and a component line 'Sunrunner' (Gorbet and Knauft 1997). Further, NuMex 01 is a high oleic acid Valencia groundnut variety developed by the New 
Mexico Agricultural State University (Puppala and Tallury 2014).

Significant genetic variability was created for morphophysiological traits such as pod yield and related traits, and oil content of groundnut through gamma irradiation (Rashid et al. 2012). Similarly, Ahmed and Mohamed (2009) reported a higher number of pods and seed yield per plant in groundnut mutants than their parents. Sui et al. (2015) reported that the use of Pingyangmycin-based in vitro mutagenesis in combination with directed screening with Hydroxyproline is effective for development of potential drought-tolerant mutants of groundnut. Induced mutagenesis particularly through combination of gamma rays and sodium azide was successful in developing mutants in groundnut with wide genetic variability (Mondal et al. 2007).

Increased pod yield, a greater number of pods per plant, higher pod filling ability, increased pod size, resistance to foliar diseases and drought tolerance are important farmers' preferred traits of groundnut in SSA (Ntare et al. 2007; Ndjeunga et al. 2010). But due to the narrow genetic base of the crop, foliar diseases (e.g. rust and late leaf spot) cause significant yield losses (Kumari et al. 2014). In SSA, mutation breeding technology has been adopted in groundnut improvement programmes. For instance, groundnut yield has been improved with the aid of mutation breeding in Uganda (Busolo-Bulafu 1991). In Egypt, groundnut mutants achieved higher pod yield, a larger number of pods, higher seed set per plant and improved shelling percentage than their parents (Ahmed and Mohamed 2009). Genetic variations induced by mutation represent a more efficient source of genetic variability than gene pools conserved by nature (Brock 1977). Thus, mutation breeding can be used as an alternative technique to induce genetic variation for desired characters. Further, mutation breeding offers an alternative and novel approach for creating unique phenotypes which can be exploited for breeding. However, some challenges including access to mutation induction facilities limits the use of this technology for groundnut improvement in SSA. The low cost of other mutation breeding technologies such ethyl methane sulphonate mutagenesis (EMS) offers opportunities for groundnut improvement in the region. Approximately 3400 groundnut mutants have been developed using EMS delivering useful genetic variation in groundnut breeding (Knoll et al. 2011).

\section{Rapid generation advancement}

Rapid generation advancement (RGA) approach uses single seed descent as the breeding method in a small screen house or glass house space (Collard et al. 2017).
Using RGA, many breeding programmes in chickpea successfully take two generations per year i.e. one in the field during the crop season and the other in offseason either in the greenhouse or in an off-season nursery (Gaur et al. 2007). In tomato, it was reported that RGA can produce a maximum of five generations per year compared to a maximum of three generations using conventional breeding methods (Bhattarai et al. 2009). In groundnut, RGA was used in breeding high oleic groundnut varieties in Spanish and Virginia Bunch varieties using controlled environment facilities that facilitated three cycles per year instead of two (ICRISAT 2017). The aim of RGA is to accelerate breeding cycles and breeding progress in many crops (Tanaka et al. 2016). Therefore, the method offers opportunities for rapid generation advancement to develop breeding populations for accelerated cultivar development (Bhattarai et al. 2009). The urgent need to develop superior and improved groundnut varieties for SSA requires accelerated methods such as RGA in cultivar development and release to boost production. The breeding procedure is reportedly cost effective and time saving (Collard et al. 2017) and should provide opportunities to accelerate groundnut breeding in the region.

Shuttle breeding uses diverse ecological environments to develop improved varieties with higher adaptability (Ortiz et al. 2007). Promising genotypes are grown simultaneously across different sites to select high-yielding genotypes (Ortiz et al. 2007). As a result, shuttle breeding can be used to develop drought tolerant, early-maturing groundnut varieties with high-yield, good seed quality, diseases and insect pest resistance and wide adaptability. In wheat (Triticum aestivum L.) shuttle breeding has been employed by the International Maize and Wheat Improvement Centre (CIMMYT) to develop wheat genotypes possessing biotic and abiotic stress tolerance, high-yield potential and good enduser quality attributes for cultivation across diverse environments (Crespo-Herrera et al. 2018; HernándezEspinosa et al. 2018). This is achieved through the introduction of new and novel sources of genetic variation from wild species, landraces, and other sources of useful alleles (i.e. mutants) to develop well-adapted genotypes (Ortiz et al. 2007).

In SSA, groundnut breeding programmes can benefit from shuttle breeding for advancing the generations that can contribute to the enhanced rate of genetic gain especially for yield. Further, the development of efficient shuttle breeding method with RGA could help significantly to reduce groundnut breeding cycles in SSA. Despite these opportunities, limited collaborative research among groundnut breeders in SSA hinder accelerated cultivar development and release. There is a need 
for financial support by key groundnut producing countries in SSA for collaborative groundnut improvement that may accelerate breeding of highly-adapted and high-yielding genotypes in the region.

\section{Single seed descent method in groundnut breeding}

Genetic gains for key traits can be delayed due to the long breeding generation required in the traditional breeding methods. Some 10-16 breeding generations are required for genetic advancement and to select desirable recombinants resulting from crosses (Saxena et al. 2017). Single Seed Descent (SSD) is most suitable for handling large segregating populations (Wells and Weiser 1989) and for accelerated cultivar development. SSD optimises resources allocation without compromising on genetic variability and genetic advancement. It reduces time for cultivar development and saves cost associated with the advancement of early generations (Teerawat and Charassri 2010). SSD has been successfully used in groundnut breeding programmes, where multiple generations per year have accelerated using the inbreeding process to progress fixed lines to multi-site evaluation trials (Holbrook and Culbreath 2008). In safflower (Carthamus tinctorius L.), SSD resulted in development of lines with higher yield and oil content producing compared with parental genotypes (Martinez et al. 1986). In pigeon pea [Cajanus cajan (L.) Millsp] development of RGA technology that integrates germination of immature seeds with single seed descent method resulted in about 3-4 generations advanced in 1 year (Saxena et al. 2017). In cowpea (Vigna unguiculata L. Walp) SSD allowed a more rapid generation than pedigree selection resulting in the development of superior genotypes (Obisesan 1992). This method could be appropriate for groundnut breeding. There is a need for a standardised and efficient SSD protocol to accelerate cultivar development in SSA.

\section{Genetic engineering and genome editing}

Genetic engineering (i.e. recombinant DNA technology, gene modification, and gene therapy) refers to the process of inserting new genetic information into existing cells in order to modify a specific organism for the purpose of changing its characteristics (Nakashima 2018). Genetic engineering techniques such as the use of Agrobacterium tumefaciens mediated transformation and DNA-bombardment-mediated transformation are used as powerful tools to accelerate groundnut improvement (Shilpa et al. 2013). The success of genetic transformation depends on a reliable tissue culture regeneration system, gene construct(s), suitable vector (s) for transformation and efficient procedures to introduce desired genes into target plants (Banavath et al. 2018). Groundnut tissues such as leaf sections, cotyledonary nodes, longitudinal cotyledon halves, embryo axes, embryo leaflets, and hypocotyls have been used for genetic transformation (Holbrook et al. 2011).

Genetic engineering of groundnut is one of the potential option for improving abiotic stress tolerance and food safety (i.e. aflatoxin contamination) (Banavath et al. 2018). Resistance to several fungal diseases (late leaf spot and rust), virus diseases (bud necrosis and tomato spotted wilt virus) and insect pests (white grub, gram pod borer) have been achieved through the application of genetic engineering in groundnut (Shilpa et al. 2013). Table 5 summarises some successful groundnut genetic transformation studies.

Genome editing is used to obtain new allelic forms which is targeted gene modification to obtain a generation of new allelic variants in the genomes of cultivated individuals (David and Repkova 2017). Various novel genome editing tools have been developed including zinc finger nucleases (ZFNs), transcription activator-like effector nucleases (TALENs), and clustered regularly interspaced short palindromic repeats/Cas9 (CRISPR/ Cas9) (Kamburova et al. 2017). These tools make double-strand breaks (DSB) in DNA followed by repairing employing error-prone non-homologous end joining (NHEJ) or homology directed repair (HDR) mechanism which leads to mutation in specific location in the genome (Mishra and Zhao 2018). In groundnut, a TIRNBS-LRR candidate gene for nematode resistance was transferred using CRISPR/Cas9 vector (Guimaraes et al. 2015). Groundnut allergy is a life-threatening food allergy. QTLs associated with aflatoxin resistance have been identified in groundnut (Guo et al. 2008). For hypoallergenic groundnuts to be safe for consumption, all genes coding for allergens can be silenced or removed resulting in aflatoxin free groundnuts, and genome editing offers an effective tool (Van de Wiel et al. 2017). Groundnut breeding programmes in SSA could hugely benefit from genetic engineering and genome editing technology to produce non-toxic groundnuts for consumption and increased trade.

In conclusion, groundnut breeding in SSA is mainly dependent on limited phenotypic selection in segregating generations resulting in low selection efficiencies. Consequently, a limited number of improved groundnut genotypes were developed and deployed. To develop climate resilient, improved varieties with resistance to biotic and abiotic stress tolerance and quality attributes there is need to employ advanced techniques in the breeding processes. These include high-throughput 
Table 5. Summary of some successful groundnut genetic transformation studies.

\begin{tabular}{|c|c|c|c|c|c|c|}
\hline Genotype & Explant & Transformation method & Promoter & Transgene & $\begin{array}{c}\text { Selectable } \\
\text { Marker }\end{array}$ & References \\
\hline TMV-2 & Embryo part & Agrobacterium mediated & CaMV $35 \mathrm{~S}$ & Tobacco Chitinase & $n p t-\|$ & Rohini et al. (2001) \\
\hline $\mathrm{JL}-24$ & Cotyledon & PROK II binary vector & CaMV 355 & $I P C V c p$ & npt-II & Sharma et al. (2000) \\
\hline K6 & $\mathrm{IL}$ & Agrobacterium mediated & CaMV 355 & $T S V-C P$ & & Mehta et al. (2013) \\
\hline$k-134$ & DEC & Agrobacterium mediated & CaMV 355 & TSV-CP & $n p t-I I$ & Mehta et al. (2013) \\
\hline $\begin{array}{l}\text { New Mexico Valencia } \\
\text { A }\end{array}$ & Cotyledon & Agrobacterium mediated & CaMV 355 & $v p 1$ & Npt-II & Qin et al. (2013) \\
\hline Georgia runner & $E A X$ & $\begin{array}{l}\text { Microprojectile } \\
\text { bombardment }\end{array}$ & $A C T-2$ & $\operatorname{Mer} A$ & GUS & Yang et al. (2003) \\
\hline BARI-2000 & Cotyledon & Agrobacterium mediated & CaMV 355 & AtNHX1 0029 & $n p t-\|$ & Asif et al. (2011) \\
\hline $\mathrm{J}-11$ & Cotyledon & Agrobacterium mediated & CaMV 355 & $I P C V c p$ & $n p t-\|$ & Sharma et al. (2000) \\
\hline Florunner & $\mathrm{EAX}$ & Agrobacterium mediated & CaMV 355 & $\begin{array}{l}\text { tswv-np + gus }+ \\
\quad \text { bar }\end{array}$ & & Brar et al. (1994) \\
\hline NC-7 & $\begin{array}{l}\text { Somatic } \\
\text { embryo }\end{array}$ & Agrobacterium mediated & CaMV 355 & PStV CP4 & hph & $\begin{array}{l}\text { Partridge-Telenko et al. } \\
\text { (2011) }\end{array}$ \\
\hline
\end{tabular}

$E A X$, embryo axes, DEC, de-embryonated, IL, immature leaf, CaMV, Cauliflower Mosaic Virus, ACT-2, Arabidopsis thaliana.

and automated phenotyping techniques, rapid generation advancement, single seed descent approach, marker assisted selection, genomic selection, genetic engineering and genome editing. Integrating new breeding tools in the groundnut breeding programmes will assist in rapid identification and selection of promising groundnut genotypes possessing useful agronomic attributes to facilitate the development of genetically superior and improved cultivars to boost production in the region. Limited collaborative research and a lack of sustainable funding from groundnut producing countries hindered the progress of groundnut variety release in SSA. Moreover, breeding programmes in SSA need to be well-equipped with both human capital and infrastructure through research collaboration and partnerships with potential institutes working on groundnut improvement.

\section{Acknowledgements}

Haramaya University, ICRISAT and the University of KwaZuluNatal are sincerely acknowledged for the all-round support of the study.

\section{Disclosure statement}

No potential conflict of interest was reported by the authors.

\section{Funding}

This work was supported by Haramaya University, ICRISAT and the University of KwaZulu-Natal.

\section{Notes on contributors}

Seltene Abady is a doctoral student at Haramaya University (Ethiopia) and University of KwaZulu-Natal (South Africa).
Hussein Shimelis (PhD) is Professor of Plant Breeding and the Deputy Director for African Centre for Crop Improvement (ACCI) at the University of KwaZulu-Natal, South Africa.

Pasupuleti Janila (PhD) is a plant breeder at International Crops Research Institute for Semi-Arid Tropics (ICRISAT), India.

Jacob Mashilo (PhD) is a Crop Scientist at the Limpopo Department of Agriculture and Rural Development, South Africa.

\section{References}

African Institute of Corporate Citizenship. 2016. Malawi Groundnut Outlook. TAURUS House Executive Offices City Centre, Along Convention Drive P/Bag 382 Lilongwe 3 Malawi.

Ahmed MSH, Mohamed SMS. 2009. Improvement of groundnut (Arachis hypogaea L. productivity under saline condition through mutation induction. World J Agric Sci. 5:680-685.

Amare K, Bushra F. 2012. Registration of BaHa-jidu and BaHagudo groundnut (Arachis hypogaea L.) varieties. East Afr J Sci. 6:79-80.

Amare KB, Negussie FB, Tsegu K. 2017. Commercial peanut cultivars for the improvement of seed physicochemicals and fatty acids. Vegetos. 30:99-103.

Alemayehu C, Berhanu A, Mulugeta T, Abdi M, Tameru A, Helge S. 2014. Opportunities and constraints of groundnut production in selected drylands of Ethiopia. DCG Report No.74. Drylands Coordination Group.

Asibuo JW, Akromah R, Safo-Kantanka O, Adu-Dapaah HK, Ohemeng-Dapaah S, Agyeman A. 2008. Chemical composition of groundnut, Arachis hypogaea (L) landraces. Afr J Biotechnol. 7:2203-2208.

Asif MA, Zafar Y, lqbal J, Iqbal MM, Rashid U, Ali GM, Arif A, Nazir F. 2011. Enhanced expression ofAtNHX1, in transgenic groundnut (Arachis hypogaea L.) improves salt and drought tolerance. Mol Biotechnol. 49:250-256.

Asthana AN, Ali M, Chaturvedi SK. 1996. Chickpea. In: Paroda RS, Chadha $\mathrm{KL}$, editor. 50 years of crop science research in India. New Delhi: Indian Council of Agricultural Research; p. 287-296.

Awada L, Phillips PWB, Smyth SJ. 2018. The adoption of automated phenotyping by plant breeders. Euphytica. 214:148.

Azad MAK, Hamid MA, Yasmine F. 2014. Enhancing abiotic stress tolerance in groundnut through induced mutation. 
In: Tomlekova NB, Kozgar MI, Wani MR, editors. Mutagenesis: exploring genetic diversity of crops. p. 331-346. doi:10.3920/ 978-90-8686-796-7_1.

Bagwan HV, Akkiraju PC. 2015. Effect of physical and chemical mutagens on rhizobium and study of mutated rhizobium activity on seed germination and antibiotic sensitivity. Int J Adv Res. 3:1045-1056.

Bai G, Ge Y, Hussain W, Baenziger PS, Graef G. 2016. A multi-sensor system for high throughput field phenotyping in soybean and wheat breeding. Comp Electr Agric. 128:181-192.

Banavath JN, Chakradhar T, Pandit V, Konduru S, Guduru KK, Akila CS, Podha S, Puli COR. 2018. Stress inducible overexpression of AtHDG11 leads to improved drought and salt stress tolerance in peanut (Arachis hypogaea L.). Front Chem. 6. doi:10.3389/fchem.2018.00034.

Bhad PG, Mondal S, Badigannavar AMJ. 2016. Genetic diversity in groundnut (Arachis hypogaea L.) genotypes and detection of marker trait associations for plant habit and seed size using genomic and genic SSRs. Crop Sci Biotechnol. 19:203-221. doi:10.1007/s12892-016-0060-1.

Bhagwat A, Krishna TG, Bhatia CRJ. 1997. Rapd analysis of induced mutants of groundnut (Arachis hypogaea L. J Genet. 76:201-208. doi:10.1007/BF02932218.

Bhattarai SP, de la Pena RC, Midmore DJ, Palchamy K. 2009. In vitro culture of immature seed for rapid generation advancement in tomato. Euphytica. 167:23-30.

Brasileiro MAC, Guerra Araujo AC, Leal-Bertioli SC, Guimarães PM. 2014. Genomics and genetic transformation in Arachis. Int J Plant Biol Res. 2:1017.

Brar GS, Cohen BA, Vick CL, Johnson GW. 1994. Recovery of transgenic peanut (Arachis hypogaea L.) plants from elite cultivars utilizing ACCELL technology. Plant J. 5:745-753.

Brock RD. 1977. Prospects and perspectives in mutation breeding. In: Muhammed A, Aksel R, von Borstel RC, editors. Genetic diversity in plants. Basic life sciences, Vol. 8. Boston (MA): Springer. p. 117-132.

Busolo-Bulafu CM. 1991. Mutation breeding of groundnuts (Arachis hypogaea L.) in Uganda. Vienna: International Atomic Energy Agency (IAEA).

Burow MD, Leal-Bertioli SC, Simpson CE, Ozias-Akins P, Chu Y, Denwar NN, Chagoya J, Starr JL, Moretzsohn MC, Pandey MK, et al. 2013. Marker-assisted selection for biotic stress resistance in peanut. In: Varshney RK, Tuberosa R, editors. Translational genomics for crop breeding. doi:10.1002/ 9781118728475.ch8.

Cilliers AJ, Swanevelder CJ. 2003. The South African germplasm collection of groundnut. Arachis Hypogaea L., and its Utility. SA J. Plant Soil. 20:93-96.

Chamberlin KD, Melouk HA, Madden R, Dillwith JW, Bannore Y, El Rassi Z, Payton M. 2011. Determining the oleic/linoleic acid ratio in a single peanut seed: a comparison of two methods. Peanut Sci. 38:78-84.

Coulibaly MA, Ntare P, Gracen Danquah BR, Gracen VE, Kwadwo O. 2017. Groundnut production constraints and farmers' preferred varieties in Niger. Int J Innov Sci Eng Technol. 4:23487968.

Chintu JMM. 2013. Breeding groundnut for resistance to rosette disease and its aphid vector, Aphis craccivora Koch in Malawi [PhD thesis]. University of KwaZulu-Natal Pietermaritzburg, Republic of South Africa.
Crespo-Herrera LA, Crossa J, Huerta-Espino J, Vargas $M$, Mondal S, Velu G, Payne TS, Braun H, Singh RP. 2018. Genetic gains for grain yield in CIMMYT's semi-arid wheat yield trials grown in suboptimal environments. Crop Sci. 58:1890-189.

Collard BCY, Beredo JC, Lenaerts B, Mendoza R, Santelices R, Lopena V, Verdeprado H, Raghavan C, Gregorio GB, Vial L, et al. 2017. Revisiting rice breeding methods-evaluating the use of rapid generation advance (RGA) for routine rice breeding. Plant Prod Sci. 20:337-352. doi:10.1080/ 1343943X.2017.1391705.

Corrado G, Rao R. 2017. Towards the genomic basis of local adaptation in landraces. Diversity (Basel). 9:51. doi:10.3390/ d9040051.

Chu Y, Holbrook CC, Timper P, Ozias-Akins P. 2007. Development of a PCR-based molecular marker to select for nematode resistance in peanut. Crop Sci. 47:841-847. doi:10.2135/cropsci2006.07.0474

David V, Řepková J. 2017. Application of next-generation sequencing in plant breeding. Czech J Genet Plant Breed. 53:89-96.

Debele S, Amare A. 2015. Integrated management of Cercospora leaf spots of groundnut (Arachis hypogaea L.) through host resistance and fungicides in Eastern Ethiopia. Afr J Plant Sci. 9:82-89. doi:10.5897/AJPS2014.1260.

Deom CM, Kapewa T, Busolo-Bulafu CM, Naidu RA, Chiyembekeza AJ, Kimmins FM. 2006. Registration of ICG 12991 peanut germplasm line. Crop Sci. 46:481.

Desmae H, Janila P, Okori P, Pandey MK, Motagi BN, Monyo E, Mponda O, Okello D, Sako D, Echeckwu C, et al. 2017. Genetics, genomics and breeding of groundnut (Arachis hypogaea L.). Plant Breed. 1-20.

Desmae H, Sones K. 2017. Groundnut cropping guide. Africa soil health Consortium. Nairobi: CAB International.

FAOSTAT. 2016. [accessed 2018 Feb 16] http: www.fao.org/ faostat/en/\#data/QC.

Favero AP, Padua JG, Costa TS, Gimenes MA, Godoy IJ, Moretzsohn MC, Michelotto MD. 2015. New hybrids from peanut (Arachis hypogaea L.) and synthetic amphidiploid crosses show promise in increasing pest and disease tolerance. Genet Mol Res. 14:16694-16703.

Faye B, Webber H, Gaiser T, Diop M, Owusu-Sekyere JD, Naab JB. 2016. Effects of fertilization rate and water availability on peanut growth and yield in Senegal (West Africa). J Sustain Develop. 9:111-131.

Faye I, Pandey MK, Hamidou F, Rathore A, Ndoye O, Vadez V, Varshney RK. 2015. Identification of quantitative trait loci for yield and yield related traits in groundnut (Arachis hypogaea L.) under different water regimes in Niger and Senegal. Euphytica. 206:631-641. doi:10.1007/s10681-015-1472-6.

Ferguson ME, Burow MD, Schulze SR, Bramel PJ, Paterson AH, Kresovich S, Mitchell S. 2004. Microsatellite identification and characterization in peanut (A. hypogaea L.). Theor Appl Genet. 108:1064-1070.

Frisch M, Melchinger AE. 2005. Selection theory for markerassisted backcrossing. Genetics. 170:909-917. doi:10.1534/ genetics.104.035451.

Gaikpa DS, Akromah R, Asibuo JW, Appiah-Kubi Z, Nyadanu D. 2015. Evaluation of yield and yield components of groundnut genotypes under Cercospora leaf spots disease pressure. Int J Agron Agric. Res. 3:66-75.

Gaur PM, Srinivasan S, Gowda CLL, Rao BV. 2007. Rapid generation advancement in chickpea. J Agric Res. 3:1-3. 
Gorbet DW, Knauft DA. 1997. Registration of 'SunOleic 95R' peanut. Crop Sci. 37:1392.

Guchi E. 2015. Stakeholders' perception about aflatoxin contamination in groundnut (arachis hypogaea L.) along the value chain actors in eastern Ethiopia. Int J Food Contam. 2:10.

Guimaraes PM, Guimaraes LA, Morgante CV, Silva Jr OB, Araujo ACG, Martins ACQ, Saraiva MAP, Oliveira TN, Togawa RC, Leal-Bertoli SCM, et al. 2015. Root transcriptome analysis of wild peanut reveals candidate genes for nematode resistance. PLoSONE. 10:e0140937. doi:10.1371/journal.pone. 0140937.

Gulluoglu L, Basal H, Onat B, Kurt C, Arioglu H. 2016. The effect of harvesting on some agronomic and quality characteristics of peanut grown in the Mediterranean region of Turkey. Field Crops Res. 21:224-232. doi: 10.17557/tjfc.20186.

Gunasekaran A, Pavadai P. 2015. Studies on induced physical and chemical mutagenesis in groundnut (Arachis hypogia). Int Lett Nat Sci. 8:25-35.

Guo BZ, Chen X, Dang P, Scully BT, Liang X, Holbrook CC, Yu J, Culbreath AK. 2008. Peanut gene expression profiling in developing seeds at different reproduction stages during Aspergillus parasiticus infection. BMC Dev. Biol. 8:12.

Guo Y, Khanal S, Tang S, Bowers JE, Heesacker AF, Khalilian N, Nagy ED, Zhang D, Taylor CA, Stalker HT, et al. 2012. Comparative mapping in intraspecific populations uncovers a high degree of macrosynteny between A-and B-genome diploid species of peanut. BMC Genomics 13: 608. doi:10. 1186/1471-2164-13-608.

Habtamu A. 2016. Review paper on mutation breeding as applied in groundnut (Arachis hypogeae L. Improv Gene Cell Therapy. 1:35-40.

HajHussein O, Assar AHB, Fraah ADM, Al Sir A. 2018. Variability heritability and genetic advance of some groundnut genotypes (Arachis hypogaea L.) under saline sodic soil. Ann Rev Res. 1:1-5.

Hampannavar MR, Khan H, Temburne BV, Janila P, Amaregouda A. 2018. Genetic variability, correlation and path analysis studies for yield and yield attributes in groundnut (Arachis hypogaea L. J Pharm Phytochem. 7:870-874.

He G, Meng R, Newman M, Gao G, Pittman RN, Prakash CS. 2003. Microsatellites as DNA markers in cultivated peanut (Arachis hypogaea L. BMC Plant Biol. 3:3. doi:10.1186/1471-2229-3-3.

Hernández-Espinosa N, Mondal S, Autrique E, Gonzalez-Santoyo H, Cross J, Huerta-Espino J, Singh RP, Guzmán C. 2018. Milling, processing and end-use quality traits of CIMMYT spring bread wheat germplasm under drought and heat stress. Field Crops Res. 215:104-112.

Herselman L, Thwaites R, Kimmins FM, Courtois B, van der Merwe PJ, Seal SE. 2004. Identification and mapping of AFLP markers linked to peanut (Arachis hypogaea L.) resistance to the aphid vector of groundnut rosette disease. Theor Appl Genet. 109:1426-1433. doi:10.1007/s00122-004-1756-z.

Holbrook CC, Dong W, Timper P, Culbreath AK, Kvien CK. 2012. Registration of peanut germplasm line TifGP-2, a nematodesusceptible sister line of 'tifguard'. J Plant Reg. 6:208-211.

Holbrook CC, Ozias-Akins P, Chu Y, Gou B. 2011. Impact of molecular genetic research on peanut cultivar development. Agronomy. 1:3-17. doi:10.3390/agronomy1010003.

Holbrook CC, Timper P, Culbreath AK, Kvien CK. 2008. Registration of 'tifguard' peanut. J Plant Reg. 2:92-94. doi: 10.3198/jpr2007.12.0662crc.
Husain F, Mallikarjuna N. 2012. Genetic diversity in Bolivian landrace lines of groundnut (Arachis hypogaea L. Ind J Genet Plant Breed. 72:384-389.

ICRISAT. 2012. Drought-tolerant groundnuts.

ICRISAT. 2017. Food industry looks forward to commercialization of high-oleic groundnut varieties in India. Happening Newsletter, March No.1739.

Jaiswal JK, Levini LA, Dakora FD. 2017. Phylogenetically diverse group of native bacterial symbionts isolated from root nodules of groundnut (Arachis hypogaea L.) in South Africa. Syst Appl Microbiol. 40:215-226.

Janila P, Nigam SN, Pandey MK, Nagesh P, Varshney RK. 2013. Groundnut improvement: use of genetic and genomic tools. Front Plant Sci. 4:1-16.

Janila P, Variath MT, Pandey MK, Desmae H, Motagi BN, Okori P, Manohar SS, Rathnakumar AL, Radhakrishnan T, Boshou Liao B, et al. 2016. Genomic tools in groundnut breeding program: status and perspectives. Front Plant Sci. doi:10. 3389/fpls.2016.00289.

Jaradat AA. 2016. Breeding oilseed crops for climate change. opportunities and constraints. In: Gupta SK, editor. Breeding oilseed crops for sustainable production. London: Academic Press; p. 421-472.

Jiang GA. 2013. Molecular markers and marker-assisted breeding in plants. In: Andersen SB, editor. Plant breeding from laboratories to fields. InTechOpen, p. 46-80. doi:10.5772/3362.

Johnson HW, Rodinson HF, Cronstrock RE. 1955. Estimation of genetic and environmental variability in soybeans. Agronomy J. 47:314-318.

Kale DM, Murty GSS, Badigannavar AM. 2004. Tg 37A - A new Trombay, groundnut variety with wide adaptation. Int Arachis Newsletter. 24:19-20.

Kamburova VS, Nikitina EV, Shermatov SE, Buriev Z, Kumpatla S, Emani C, Abdurakhmonov I. 2017. Genome editing in plants: an overview of tools and applications. Hindawi Int J Agron. doi:10.1155/2017/7315351.

Kamika I, Takoy LL. 2011. Natural occurrence of aflatoxin B1 in peanut collected from Kinshasa, democratic Republic of Congo. Food Contam. 22:1760-1764.

Kanyika BTN, Davies D, Mweetwa AM, Kaimoyo E, Njung'e VM, Monyo ES, Siambi M, He G, Prakash CS, Zhao Y, et al. 2015. Identification of groundnut (Arachis hypogaea) SSR markers suitable for multiple resistance traits QTL mapping in African germplasm. Electr J Biotechnol. 18:61-67.

Kebede A, Abady S, Endale E, Abdulahi J, Getahun A, Aliyi Robsa A, Yohanese Petros Y. 2017. Registration of 'babile1 ', 'babile-2', and 'babile-3' groundnut varieties. East Afr J Sci. 11:59-64.

Kebede BA, Getahun A. 2017. Adaptability and stability analysis of groundnut genotypes using AMMI model and GGE-biplot. J Crop Sci Biotechnol. 20:343-349. doi:10.1007/s12892.

Knoll JE, Ramos ML, Zeng Y, Holbrook CC, Chow M, Chen S, Maleki S, Bhattacharya A, Ozias-Akins P. 2011. Tilling for allergen reduction and improvement of quality traits in peanut (Arachis hypogaea L.). BMC Plant Biol. 11:81.

Kulthe MH, Kothekar VS. 2011. Effects of sodium azide on yield parameters of chickpea (Cicer arietinum L.). J Phytol. 3:39-42.

Kumari V. 2008. Morphological and molecular characterization of induced mutants in groundnut [MSc dissertation], University of Agricultural Sciences, Darwat, India.

Kumari V, Gowda MVC, Tasiwal V, Pandey MK, Bhat RS, Mallikarjuna N, Upadhyaya HD, Rajeev K, Varshney RK. 
2014. Diversification of primary gene pool through introgression of resistance to foliar diseases from synthetic amphidiploids to cultivated groundnut (Arachis hypogaea L.). Crop J. 2:110-119.

Kumpatla SP, Buyyarapu R, Abdurakhmonov IY, Mammadov JA. 2012. Genomics-assisted plant breeding in the 21st Century. In: Abdurakhmonov I, editor. Technological advances and progress. InTech; p. 132-184.

Kushwah A, Gupta S, Sharma SR, Pradhan K. 2017. Genetic variability, correlation coefficient and path coefficient analysis for yield and component traits in groundnut. Ind J Ecol. 44:85-89.

Liang Y, Baring M, Wang S, Septiningsih EM. 2017. Mapping QTLs for leaf spot resistance in peanut using snp-based next-generation sequencing markers. Plant Breed Biotechnol. 5:115-122. doi:10.9787/PBB.2017.5.2.115.

Lopes MS, El-Basyoni I, Baenziger PS, Singh S, Royo C, Ozbek K, Aktas H, Ozer E, Ozdemir F, Manickavelu A, et al. 2015. Exploiting genetic diversity from landraces in wheat breeding for adaptation to climate change. J Exp Bot. 66:34773486. doi:10.1093/jxb/erv122.

Luis JM, Ozias-Akins P, Holbrook CC, Kemerait RC, SniderJr.JL, Liakos V. 2016. Phenotyping peanut genotypes for drought tolerance. Peanut Sci. 43:36-48.

Mace ES, Phong DT, Upadhyayaet HD, Chandra S, Crouch JH. 2006. SSR analysis of cultivated groundnut (Arachis hypogaea L.) germplasm resistant to rust and late leaf spot diseases. Euphytica. 152:317-330. doi:10.1007/s10681-006-9218-0.

Magamba K, Matumba L, Matita G, Gama AP, Singano L, Monjerezi M, Njoroge SM. 2017. Aflatoxin risk management in commercial groundnut products in Malawi (Sub-Saharan Africa): a call for a more socially responsible industry. J Consum Prot Food Saf. 12:309-316.

Mallikarjuna N, Senthilvel S, Hoisington D. 2011. Development of new sources of tetraploid Arachis to broaden the genetic base of cultivated groundnut (Arachis hypogaea L.). Genet Resour Crop Evol. 58: 889. doi:10.1007/s10722-010-9627-8.

Maluszynski M. 2001. Officially released mutant varieties - The FAO/IAEA database. Plant Cell Tiss Organ Cult. 65:175-177.

Martinez JF, Gimenez JD, Jimenez A, Hernandez L. 1986. . Use of the single seed descent method in breeding safflower (Carthamus tinctorius L.). Plant Breed. 97:364-367.

Mastewal A, Sakhuja PK, Mashilla D. 2017. Evaluation of released and local groundnut varieties against groundnut rust (Puccinia arachidis) at Babile, Eastern Ethiopia. Open Acc J Agric Res. 2:000123.

Mehta R, Radhakrishnan T, Kumar A, Yadav R, Dobaria JR, Thirumalaisamy PP, Jain RK, Chigurupati P. 2013. Coat protein-mediated transgenic resistance of peanut (Arachis hypogaea L.) to peanut stem necrosis disease through Agrobacterium-mediated genetic transformation. Ind J Virol. 24:205-213. doi:10.1007/s13337-013-0157-9.

Mhlaba ZB, Shimelis HA, Amelework B, Modi AT, Mashilo J. 2018. Variance components and heritability of yield and yield-related traits in tepary bean (Phaseolus acutifolius). S Afr J Plant Soil. doi:10.1080/02571862.2018.1487593.

Michelotto MD, de Godoy IJ, dos Santos JF, Martins ALM, Leonardecz E, Favero AP. 2016. Identifying Arachis amphidiploids resistant to foliar fungal diseases. Crop Sci 56:17921798.

Michelotto MD, de Godoy IJ, Pirotta MZ, dos Santos JF, Finoto EL, Favero AP. 2017. Resistance to thrips (Enneothrips flavens) in wild and amphidiploid Arachis species. PLoS ONE. 12:e0176811.

Mienie CMS, Pretorius AE. 2013. Application of marker-assisted selection for ahFAD2A and ahFAD2B genes governing the high-oleic acid trait in South African groundnut cultivars (Arachis hypogaea L.). Afr J Biotechnol. 12:4283-4289.

Minde I, Madzonga O, Kantithi G, Phiri K, Pedzisa T. 2008. Constraints, challenges, and opportunities in groundnut production and marketing in Malawi. Report No. 4.

Mishra R, Zhao K. 2018. Genome editing technologies and their applications in crop improvement. Plant Biotechnol Rep. 12:57-68. doi:10.1007/s11816-018-0472-0.

Mondal S, Badigannavar AM. 2013. A narrow leaf groundnut mutant, TMV2-NLM has a $G$ to A mutation in AhFAD2A gene for high oleate trait. Ind J Genet. 73:105-109. doi:10. 5958/j.0019-5200.73.1.016.

Mondal S, Badigannavar AM, D'Souza SF. 2012. Development of genic molecular markers linked to a rust resistance gene in cultivated groundnut (Arachis hypogaea L.). Euphytica. 188:163-173. doi:10.1007/s10681-011-0619-3.

Mondal S, Badigannavar AM, Kale DM, Murty GSS. 2007. Induction of genetic variability in a disease resistant groundnut breeding line. Newsletter, Founders day special issue 285.

Mondal S, Hande P, Badigannavar AM. 2014. Identification of transposable element markers for a rust (Puccinia arachidis Speg.) resistance gene in cultivated peanut. J Phytopathol. 162:548-552. doi:10.1111/jph.12220.

Monyo ES, Njoroge SMC, Coe R, Osiru M, Madinda F, Waliyar F, Thakur RP, Chilunjika T, Anitha S. 2012. Occurrence and distribution of aflatoxin contamination in groundnuts (Arachis hypogaea L) and population density of Aflatoxigenic aspergilli in Malawi. Crop Protec. 42:149-155.

Monyo ES, Varshney RK. 2016. Seven seasons of learning and engaging smallholder farmers in the drought-prone areas of sub-Saharan Africa and South Asia through Tropical Legumes, 2007-2014. ICRISAT, Patancheru.

Motagi BN, Vabi MB, Ajeigbe HA, Echekwu CA, Mohammed SG. 2016. Designing effective groundnut breeding strategies through farmers-breeder interactions in Northern Nigeria. 2nd International Conference on Drylands (12th - 16th December 2016). ICRISAT, Patancheru, India; p. 248-249.

Mothilal A (2012) Groundnut. In: Gupta S, editor. Technological innovations in major world oil crops, Volume 1. New York (NY): Springer. doi:10.1007/978-1-4614-0356-2_13.

Muitia A. 2011. Farmer perceptions and genetic studies of rosette disease in groundnut (Arachis hypogaea L.) in northern Mozambique [PhD thesis], University of KwaZulu-Natal, South Africa.

Nadaf HL, Kaveri SB, Madhusudan K, Motagi BN. 2009. Induced genetic variability for yield and yield components in peanut (Arachis hypogaea L.). In: Shu QY, editor. Induced plant Mutations in the Genomics Era. Rome: Food and Agriculture Organization of the United Nations (FAO); p. 346-348.

Naeem-UD-Din AM, Gul SSK, lqbal S, Muhammad FH. 2009. High yielding groundnut (Arachis hypogea L.) variety "golden". Pak J Bot. 41:2217-2222.

Nagy ED, Chu Y, Guo Y, Khanal S, Tang S, Li Y, Dong WB, Timper P, Taylor C, Ozias-Akins $P$, et al. 2010. Recombination is suppressed in an alien introgression in peanut harboring $\mathrm{Rma}$, a dominant root-knot nematode resistance gene. Mol Breed. 26:357-370. 
Nakashima K, Kanamori N, Nagatoshi Y, Fujita Y, Takasaki H, Urano K, Mogami J, Mizoi J, Mertz-Henning LM, Neumaier $\mathrm{N}$, et al. 2018. Application of biotechnology to generate drought-tolerant soybean plants in Brazil: development of genetic engineering technology of crops with stress tolerance against degradation of global environment. In: Kokubun M, Asanuma S, editors. Crop production under stressful conditions. Singapore: Springer. doi:10.1007/978981-10-7308-3_7.

Nath UK, Alam MS. 2002. Genetic variability, heritability and genetic advance of yield and related traits of groundnut (Arachis hypogaea L.). J Biol Sci. 2:762-764.

Ndjeunga J, Ntare BR, Abdoulaye A, Ibro A, Zarafi MA, Cisse Y, Moutari A, Kodio O, Echekwu CA, Mohammed SG, et al. 2010. Farmer preferences for groundnut traits and varieties in West Africa: Cases of Mali, Niger and Nigeria. Working paper Series no. 27. Working paper. International Crops Research Institute for the Semi-Arid Tropics, Patancheru, Andhra Pradesh, India.

Ngirazi NS, Manjeru P, Ncube B. 2017. Assessment of genotype $x$ environment interaction and pod yield evaluation of groundnut (Arachis hypogaea L.) genotypes in Zimbabwe. Afr J Plant Sci. 11:54-60.

Njoroge SMC, Matumba L, Kanenga K, Siambi M, Waliyar F, Maruwo J, Machinjiri N, Monyo ES. 2017. Aflatoxin B1 levels in groundnut products from local markets in Zambia. Mycotoxin Res. 33:113.

Ntare BR, Ndjeunga J, Waliyar F, Kodio O, Echekwu CA, Kapran I, Da Sylva A, Diallo AT, Amadou A, Bissala HY, et al. 2007. Farmer participatory evaluation and dissemination of improved groundnut varieties in West Africa. International Crops Research Institute for the Semi-Arid Tropics (ICRISAT). p. 36.

Obisesan IO. 1992. Evaluation of pedigree and single seed descent selection methods for cultivar development in cowpea (Vigna unguiculata L. Walp). Plant Breed. 108:162168.

Okello DK, Biruma M, Deom CM. 2010. Overview of groundnuts research in Uganda: past, present and future. Afr J Biotechnol. 9:6448-6459.

Okello DK, Deom CM, Puppala N, Monyo E, Bravo-Ureta B. 2016. Registration of 'serenut $5 R^{\prime}$ groundnut. J Plant Reg. 10:115-118.

Okello DK, Deom CM, Puppala N, Monyo E, Bravo-Ureta B. 2018. Registration of 'serenut $6 \mathrm{~T}^{\prime}$ groundnut. J Plant Reg. 12:43-47.

Ortiz R, Trethowan R, Ferrara GO, Iwanaga M, Dodds JH, Crouch JH, Crossa J, Braun HJ. 2007. High yield potential, shuttle breeding, genetic diversity, and a new international wheat improvement strategy. Euphytica. 157:365-384. doi:10. 1007/s10681-007-9375-9.

Oteng-Frimpong R, Sriswathi M, Ntare BR, Dakora FD. 2015. Assessing the genetic diversity of 48 groundnut (Arachis hypogaea L.) genotypes in the Guinea savanna agroecology of Ghana, using microsatellite-based markers. Afr J Biotechnol. 14:2484-2493. doi: 10.5897/AJB2015.14770.

Pandey MK, Monyo E, Ozias-Akins P, Liang X, Guimarães $P$, Nigam SN, Upadhyaya HD, Janila P, Zhang X, Guo B, et al. 2012. Advances in Arachis genomics for peanut improvement. Biotechnol Adv. 30:639-651. doi: 10.1016/j. biotechadv.2011.11.001.
Partridge-Telenko DE, Hu J, Livingstone DM, Shew BB, Phipps PM, Grabau EA. 2011. Sclerotinia blight resistance in Virginia-type peanut transformed with a barley oxalate oxidase gene. Phytopathol. 101:786-793.

Patrick A, Pelham S, Culbreath A, Holbrook CC, de Godoy IJ, Li C. 2017. High throughput phenotyping of tomato spot wilt disease in peanuts using unmanned aerial systems and multispectral imaging. IEEE Instr Measur Mag. 20:4-12.

Puppala N, Tallury SP. 2014. Registration of 'NuMex 01' high oleic Valencia peanut. J Plant Reg. 8:127-130. doi:10.3198/ jpr2013.11.0070crc.

Qin H, Gu Q, Kuppu S, Sun L, Zhu X, Mishra N, Hu R, Shen G, Zhang J, Zhang Y, et al. 2013. Expression of the Arabidopsis vacuolar $\mathrm{H}$ +-pyrophosphatase gene AVP1 in peanut to improve drought and salt tolerance. Plant Biotechnol Rep. 7:345-355.

Rashid JA, Alam MS, Moniruzzaman M, Salim M, Azad MAK, Nat UK. 2012. Genetic study of groundnut (Arachis hypogaea L.) mutants for their yield attributes and oil content. Bangl J Progr Sci Technol. 10:181-186.

Remanandan P. 1996. Landraces of the primitive pigeonpea yield economic benefit and contribute to sustainability. Diversity (Basel). 12:58.

Resende MFR, Muzon JP, Acosta JJ, Peter GF, Davis JM, Grattapaglia D, Resende MD, Kirst M. 2012. Accelerating the omestication of trees using genomic selection: accuracy of prediction models across ages and environments. New Phytol. 193:617-624. doi:10.1111/j.1469-8137.2011.03895.x.

Rohini VK, Rao KS. 2001. Transformation of peanut (Arachis hypogaea L.) with tobacco chitinase gene: variable response of transformants to leaf spot disease. Plant Sci. 160:889-898. doi:10.1016/S0168-9452(00)00462-3.

Sánchez PAG, Mesa HJ, Montoya MM. 2016. Next generation sequence analysis of the forage peanut (Arachis pintoi) virome. Revista Facultad Nacional de Agronomía. doi:10. 15446/rfna.v69n2.59133.

Sanchez-Dominguez S, Williams DE. 1993. Results of a recent plant exploration in Mexico to collect the hirsuta peanut. Proc Amer Peanut Res Educ Soc. 25:35. (abstr.).

Saxena K, Saxena RK, Varshney RK. 2017. Use of immature seed germination and single seed descent for rapid genetic gains in pigeonpea. Plant Breed. 136:954-957.

Setimela P, Prasanna BM, Worku M, Okori P. 2017. Variety release and registration of public bred varieties and land races. SADC Technical Meeting 13-17 November 2017. CIMMYT, Mexico.

Shakoor N, Lee S, Mockler TC. 2017. High throughput phenotyping to accelerate crop breeding and monitoring of diseases in the field. Curr Opinion Plant Biol. 38:184-192.

Sharma B. 1996. Other pulses. In: Paroda RS, Chadha KL, editor. 50 years of crop science research in India. New Delhi: Indian Council of Agricultural Research; p. 297-317.

Sharma K, Anjaiah V. 2000. An efficient method for the production of transgenic plants of peanut (Arachis hypogaea L.) through agrobacterium tumefaciens-mediated genetic transformation. Plant Sci. 159:7-19. doi:10.1016/S0168-9452 (00)00294-6.

Sharma NH, Bisen P, Dhakar TR, Bhumica Singh B, Jain S. 2017 a. Diversity Assessment among groundnut (Arachis hypogaea L.) genotypes using RAPD markers. Ind J Ecol. 44:838-842.

Sharma S, Pandey MK, Sudini HK, Upadhyaya HD, Varshney RK. 2017b. Harnessing genetic diversity of wild Arachis species 
for genetic enhancement of cultivated peanut. Crop Sci. 57:1121-1131. doi:10.2135/cropsci2016.10.0871.

Shasidhar Y, Vishwakarma MK, Pandey MK, Janila P, Variath MT, Manohar SS, Nigam SN, Guo B, Varshney RK. 2017. Molecular mapping of oil content and fatty acids using dense genetic maps in groundnut (Arachis hypogaea L.). Front Plant Sci. 8:794. doi:10.3389/.

Shilpa K, Sunkad G, Kurella S, Marri S, Padmashree K, Jadhav DR, Sahrawat KL, Mallikarjuna N. 2013. Biochemical composition and disease resistance in newly synthesized amphidiploid and autotetraploid peanuts. Food Nutr Sci. 4:169-176. doi:10.4236/fns.2013.42024.

Shoba D, Manivannan N, Vindhiyavarman P, Nigam SN. 2012. Ssr markers associated for late leaf spot disease resistance by bulked segregant analysis in groundnut (Arachis hypogaea L.). Euphytica. 188:265-272. doi:10.1007/s10681-0120718-9.

Simpson CE, Starr JL, Baring MR, Burow MD, Cason JM, Wilson JN. 2013. Registration of 'webb' peanut. J. Plant. Reg. 7:265-268.

Simpson CM, Star JL, Church GT, Burrow MD, Paterson AH. 2003. Registration of NemaTAM peanut. (Registrations of cultivar). Crop Sci. 43:1561.

Singh AK. 1986. Utilization of wild relatives in the genetic improvement of Arachis hypogaea L. 8. Synthetic amphidiploids and their importance in interspecific breeding. Theor Appl Genet. 72:433-439.

Singh AK, Nigam SN. 2016. Arachis gene pools and genetic improvement in groundnut. In: Rajpal VR, Rao S, Raina S, editors. Gene pool diversity and crop improvement, sustainable development and biodiversity, Volume 10. Springer International Publishing Switzerland. doi:10.1007/978-3319-27096-8.

Sorrells ME. 2015. Genomic selection in plants: empirical results and implications for wheat breeding. In: Ogihara Y, Takumi S, Handa $\mathrm{H}$, editors. Advances in wheat genetics: from genome to field. Tokyo: Springer. doi:10.1007/978-4-43155675-6_45.

Stalker HT, Mozingo LG. 2001. Molecular markers of Arachis and marker-assisted selection. Peanut Sci. 28:117-123.

Sui J, Wang Y, Wang P, Qiao L, Sun S, Hu X, Chen J, Wang J. 2015. Generation of peanut drought tolerant plants by Pingyangmycin-mediated in vitro mutagenesis and hydroxyproline-resistance screening. PLoSONE. 10:e0119240. doi:10. 1371/ journal.pone.0119240.

Sun C, van Raden PM, Cole JB, O'Connell JR. 2014. Improvement of prediction ability for genomic selection of dairy cattle by including dominance effects. PLoSONE. 9:e103934. doi:10. 1371/journal.pone.0103934.

Sundaram J, Kandala CV, Holser RA, Butts CL, Windham WR. 2010. Determination of in-shell peanut oil and fatty acid composition Using Near-Infrared Reflectance Spectroscopy. J Am Oil Chem Soc. 87:1103-1114

Tallury SP, Isleib TG, Copeland SC, Rosas-Anderson P, Balota M, Singh D, Stalker HT. 2014. Registration of two multiple disease-resistant peanut germplasm lines derived from Arachis cardenasii Krapov. \& W.C. Gregory, GKP 10017. J Plant Reg. 8:86-89.

Tanaka J, Hayashi T, Iwata H. 2016. A practical, rapid generationadvancement system for rice breeding using simplified biotron breeding system. Breeding Sci. 66:542-551.
Teerawat S, Charassri N. 2010. The efficiency of pedigree and single seed descent selections for yield improvement at generation 4 (F4) of two yardlong bean populations. Kasetsart J. (Natural Science. 44:343-352.

Tiwari S, Tripathi MK, Kumar N, Tomar RS, Joshi E, Tiwari R, Gupta R, Singh AK. 2017. Improvement of groundnut for fatty acids using marker assisted breeding approaches. Int J Pure Appl Biosci. 5:59-63. doi:10.18782/2320-7051.5952.

Upadhyaya HD, Bramel PJ, Ortiz R, Singh S. 2002. Developing a mini core of peanut for utilization of genetic resources. Crop Sci. 42:2150-2156.

Upadhyaya HD, Dwivedi SL, Vadez V, Hamidou F, Singh S, Varshney RK, Liao B. 2014. Multiple resistant and nutritionally dense germplasm identified from mini core collection in peanut. Crop Sci. 54:679-693.

Upadhyaya HD, Ferguson ME, Bramel PJ. 2001a. Status of the Arachis germplasm collection at ICRISAT. Peanut Sci. 28:8996.

Upadhyayaa HD, Mallikarjuna Swamyb BP, Kenchana Goudarb PV, Kullaiswamy BY, Singha S. 2005. Identification of diverse groundnut germplasm through multie-nvironment evaluation of a core collection for Asia. Field Crops Res. 93:293-299.

Upadhyaya HD, Nigam SN, Mehan VK, Reddy AGS, Yellaiah N. $2001 \mathrm{~b}$. Registration of Aspergillus flavus seed infection resistant peanut germplasm ICGV 91278, ICGV 91283, and ICGV 91284 Registration by CSSA. Crop Sci 41:599-600.

Van de Wiel CCM, Schaart JG, Lotz LAP, Smulders MJM. 2017. New traits in crops produced by genome editing techniques based on deletions. Plant Biotechnol Rep. 11:1-8. doi:10. 1007/s11816-017-0425-z.

Variath MT, Janila P. 2017. Economic and Academic Importance of peanut. In: Varshney R, Pandey M, Puppala N, Editors. The peanut genome. Compendium of plant genomes. Cham: Springer. doi:10.1007/978-3-319-63935-2_2.

Varshney RK, Bertioli DJ, Moretzsohn MC, Vadez V, Krishnamurthy L, Aruna R, Nigam SN, Moss BJ, Seetha K, Ravi K, et al. 2009. The first SSR-based genetic linkage map for cultivated groundnut (Arachis hypogaea L.). Theor Appl Genet. 118:729-39. doi:10.1007/s00122-008-0933-x.

Varshney RK, Gowda MVC, Radhakrishnan T, Pandey MK, Gautami B, Sujay V, Koppolu R, Senthilvel S, Vadez V, Nigam SN, et al. 2010. Development and application of genomic resources for molecular breeding in groundnut (Arachis hypogaea L). Proc: The 3rd International Conference on plant molecular breeding (ICPMB), 5-9th September. Beijing, China.

Varshney RK, Mohan SM, Gaur PM, Gangarao NVPR, Pandey MK, Bohra A, Sawargaonkar SL, Chitikineni A, Kimurto PK, Janila P, et al. 2013. Achievements and prospects of genomicsassisted breeding in three legume crops of the semi-arid tropics. Biotechnol Adv. 31:1120-1134.

Varshney RK, Pandey MK, Janila P, Nigam SN, Sudini H, Gowda MCV, Sriswathi M, Radhakrishnan T, Manohar SS, Nagesh P. 2014. Marker-assisted introgression of a QTL region to improve rust resistance in three elite and popular varieties of peanut (Arachis hypogaea L.). Theor Appl Genet. 127:1771-1781. doi:10.1007/s00122-014-2338-3.

Waliyar F, Hassan H, Bonkoungou S. 1994. Sources of resistance to Aspergillus flavus and aflatoxin contamination in groundnut genotypes in West Africa. Plant Dis. 78:704-708. 
Waliyar F, Kumar KVK, Diallo M, Traore A, Mangala UN, Upadhyaya HD, Sudini H. 2016. Resistance to pre-harvest aflatoxin contamination in ICRISAT's groundnut mini core collection. Eur J Plant Pathol. 145:901-913.

Wang H, Lei Y, Yan L, Wan L, Cai Y, Yang Z, Lv J, Zhang X, Xu C, Liao B. 2018. Development and validation of simple sequence repeat markers from Arachis hypogaea transcript sequences. Crop J. 6:172-180. doi:10.1016/j.cj.2017.09.007.

Wells WC, Weiser GC. 1989. Additive genetic variance within populations derived by single-seed descent and pod-bulk descent. Theor Appl Genet. 78:365-368. doi:10.1007/s10681-007-9375-9.

Wu L, Chen J, Shi Y, Miao H, Hu W, Qi W, Chen X. 2006. Breeding of Huayu 22 by $60 \mathrm{Co} Y$-rays mutagenesis combined with hybridization. Acta Agric Nucl Sinica. 20:309-311.

Yang H, Nairn J, Ozias-Akins P. 2003. Transformation of peanut using a modified bacterial mercuric ion reductase gene driven by an actin promoter from Arabidopsis thaliana. J Plant Physiol. 160:945-952.

Yin D, Wang Y, Zhang X, Ma X, He X, Zhang J. 2017. Development of chloroplast genome resources for peanut (Arachis hypogaea L.) and other species of Arachis. Sci Rep. 7:11649. doi:10.1038/s41598-017-12026-x.
Yusuf Z, Zeleke H, Mohammed W, Hussein S, Hugo A. 2017. Genetic progress for yield, yield components and other agronomic characters of groundnut (Arachis Hypogea L.) cultivars in eastern Ethiopia. Int J Plant Breed Crop Sci. 4:237-242.

Zhao Y, Prakash CS, He G. 2012. Characterization and compilation of polymorphic simple sequence repeat (SSR) markers of peanut from public database. MC Res Notes. 5:362.

Zhao Y, Zhang C, Chen H, Yuan M, Nipper R, Prakash CS, Zhuang W, He G. 2016. Qtl mapping for bacterial wilt resistance in peanut (Arachis hypogaea L.). Mol Breed. 36:13.

Zongo A, Khera P, Sawadogo $M$, Shasidhar $Y$, Sriswathi $M$, Vishwakarma MK, Sankara P, Ntare BR, Varshney RK, Pandey MK, et al. 2017b. SSR markers associated to early leaf spot disease resistance through selective genotyping and single marker analysis in groundnut (Arachis hypogaea L.). Biotechnol Rep. 15:132-137.

Zongo A, Nana AT, Sawadogo M, Konate AK, Sankara P, Ntare BR, Desmae H. 2017a. Variability and correlations among groundnut populations for early leaf spot, pod yield, and agronomic traits. Agronomy. 7:52. doi:10.3390/ agronomy7030052. 